\title{
Profiling of fine and coarse particle mass: case studies of Saharan dust and Eyjafjallajökull/Grimsvötn volcanic plumes
}

\author{
A. Ansmann ${ }^{1}$, P. Seifert ${ }^{1}$, M. Tesche ${ }^{2}$, and U. Wandinger ${ }^{1}$ \\ ${ }^{1}$ Leibniz Institute for Tropospheric Research, Leipzig, Germany \\ ${ }^{2}$ Department of Applied Environmental Science, Stockholm University, Stockholm, Sweden
}

Correspondence to: A. Ansmann (albert@tropos.de)

Received: 7 May 2012 - Published in Atmos. Chem. Phys. Discuss.: 30 May 2012

Revised: 20 September 2012 - Accepted: 25 September 2012 - Published: 17 October 2012

\begin{abstract}
The polarization lidar photometer networking (POLIPHON) method introduced to separate coarse-mode and fine-mode particle properties of Eyjafjallajökull volcanic aerosols in 2010 is extended to cover Saharan dust events as well. Furthermore, new volcanic dust observations performed after the Grimsvötn volcanic eruptions in 2011 are presented. The retrieval of particle mass concentrations requires mass-specific extinction coefficients. Therefore, a review of recently published mass-specific extinction coefficients for Saharan dust and volcanic dust is given. Case studies of four different scenarios corroborate the applicability of the profiling technique: (a) Saharan dust outbreak to central Europe, (b) Saharan dust plume mixed with biomass-burning smoke over Cape Verde, and volcanic aerosol layers originating from (c) the Eyjafjallajökull eruptions in 2010 and (d) the Grimsvötn eruptions in 2011. Strong differences in the vertical aerosol layering, aerosol mixing, and optical properties are observed for the different volcanic events.
\end{abstract}

\section{Introduction}

The eruptions of the Eyjafjallajökull volcano in April-May 2010 triggered the development of a variety of new lidarbased methods to identify ash and dust particles ${ }^{1}$ in volcanic aerosol plumes containing fine and coarse particles. These new lidar profiling techniques further allow us to quantify the optical properties of the volcanic ash and dust particles (coarse-mode) and to estimate their mass concentration as

\footnotetext{
${ }^{1}$ Volcanic ash and dust particles have diameters $>60 \mu \mathrm{m}$ and $<60 \mu \mathrm{m}$, respectively. By the same diameter of $60 \mu \mathrm{m}$, desert sand and dust particles (silt-sized and background dust) are separated.
}

a function of height (Ansmann et al., 2011b; Gasteiger et al., 2011; Marenco and Hogan, 2011; Miffre et al., 2011; Chaikovsky et al., 2012; Wagner et al., 2012; Veselovskii et al., 2012).

A powerful aerosol remote sensing station, combining profiling with column monitoring techniques, is equipped with polarization lidar (or advanced polarization ceilometer) and sun-sky photometer (Müller et al., 2003; Ansmann et al., 2011b). The polarization lidar permits the discrimination of light-depolarizing coarse-mode particles (non-spherical particles) such as volcanic dust and desert dust and nonlight-depolarizing fine-mode particles (spherical particles) such as anthropogenic haze and volcanic sulfate particles (Sakai et al., 2003a; Murayama et al., 2003; Sugimoto et al., 2003; Shimizu et al., 2004; Sugimoto and Lee, 2006; Sassen, 2005; Sassen et al., 2007; Nishizawa et al., 2007; Liu et al., 2008; Freudenthaler et al., 2009; Groß et al., 2011a, 2012; Miffre et al., 2012). The technique further allows us to determine the profiles of the coarse-mode-related and fine-mode-related backscatter coefficient (Shimizu et al., 2004; Tesche et al., 2009b, 2011b), and thus the estimation of the corresponding particle extinction coefficient profiles for the fine and coarse-mode fraction by means of appropriate extinction-to-backscatter ratios (lidar ratios). The sunsky photometer, on the other hand, provides spectrally resolved column-integrated particle extinction values (aerosol optical thickness, AOT) and permits the retrieval of finemode- and coarse-mode-related AOTs (O'Neill et al., 2003; Dubovik et al., 2006) and of microphysical particle properties such as volume and surface-area concentrations for the fine-mode and coarse-mode fractions (Dubovik and King, 2000; Dubovik et al., 2006). Toledano et al. $(2011,2012)$ 
demonstrate the usefulness of sun-sky photometry in cases of complex aerosol scattering conditions. These photometer observations provide volume-to-extinction conversion factors which in combination with estimates of particle mass density allow us to retrieve particle mass concentration profiles from the lidar-derived extinction profiles.

It has been demonstrated that a single-wavelength polarization lidar in combination with sun-sky photometry provides a comparably simple, robust and practical way to retrieve profiles of coarse and fine particle mass concentrations (Ansmann et al., 2011b). Instrumentation, for which high quality measurement standards can be maintained over long time periods, in combination with likewise simple data processing schemes is of advantage for continuous network monitoring of the spread of aerosol plumes over days and weeks with high vertical and temporal resolution. This particle mass profiling (PMAP) polarization lidar photometer networking (POLIPHON) method can be regarded as one of the basic techniques for detailed height-resolved profiling of optical and microphysical properties of atmospheric particles. Polarization lidars equipped not only with elastic backscatter channels but also with nitrogen Raman channels increase the potential of such a monitoring site by independently measuring vertical profiles of particle backscatter and extinction coefficients (Ansmann et al., 1992; Ansmann and Müller, 2005; Shcherbakov, 2007; Samoilova and Balin, 2008; Pornsawad et al., 2012) and by providing direct observations on the relationship between backscatter and extinction (lidar ratio) for desert dust, volcanic dust, and for layers with mixtures of dust and fine-mode particles (Mattis et al., 2002, 2010; Pappalardo et al., 2004; Müller et al., 2007; Wang et al., 2008; Tesche et al., 2009a, 2011a; Wiegner et al., 2011, 2012; Groß et al., 2011b, 2012; Mona et al., 2012; Papayannis et al., 2012; Sicard et al., 2012).

Here we extend the application of our lidar-photometer method which was successfully used in the analysis of European Aerosol Lidar Network (EARLINET) observations of the Eyjafjallajökull volcanic aerosol plumes in central and southwestern Europe (Ansmann et al., 2011b; Sicard et al., 2012). We include Saharan dust observations. In the course of the discussion, an extended review of recent measurements of mass-specific extinction coefficients for Saharan and volcanic dust is presented. Such specific extinction coefficients are required to convert measured particle optical properties into mass concentration information. After the introduction of the methodology in Sect. 2, applications of the technique are discussed in Sect. 3. These case studies include unique observations of (a) a lofted Saharan dust plume as typically observed over central Europe after Saharan dust outbreaks (Ansmann et al., 2003; Papayannis et al., 2008; Wiegner et al., 2011), (b) mixtures of desert dust with biomass-burning aerosol as observed at Cape Verde during the Saharan Mineral Dust Experiment 2 (SAMUM2) (Ansmann et al., 2011a; Tesche et al., 2011a,b; Groß et al., 2011a,b), and (c) and (d) volcanic aerosol plumes (mixtures of volcanic dust and sulfate particles) after the Eyjafjallajökull volcanic eruption in April 2010 (Ansmann et al., 2011b) and after the eruptions of the Grimsvötn volcano on Iceland in May 2011 (Kerminen et al., 2011; Tesche et al., 2012).

\section{Method}

We briefly summarize the data processing scheme and extend the methodology towards desert dust aerosols. An overview of the different steps of the retrieval procedure is given in Table 1 . The instruments, retrieval methods, and uncertainties are discussed by Tesche et al. (2009b, 2011b,c) and Ansmann et al. (2011b). A well-designed, well-calibrated polarization lidar enabling high-quality observations of the volume linear depolarization ratio, e.g, at $532 \mathrm{~nm}$ wavelength, is a basic prerequisite for successful observations (Freudenthaler et al., 2009). The degree of linear polarization and polarization plane of the transmitted laser light, depolarization effects introduced by the transmission and reflection properties of the beam steering elements and the receiver channel optics, and the receiver filter band width have to be fully taken into account in the analysis of lidar measurements of the volume (Rayleigh plus particle) depolarization ratio. The Rayleigh contribution to the measured volume depolarization ratio is of the order of 0.01 (one percent) in the case of the lidars used here. Furthermore, when combining lidar and photometer observations, it would be desirable to cover the entire tropospheric column from the surface to the tropopause with lidar observations. However, lidars do not see the lowermost aerosol layers (in the so-called near-range of the lidar with an incomplete overlap of the laser beam with the receiver field of view) so that estimates of particle extinction in these lowest layers to the tropospheric AOT have to be made and may introduce uncertainties in the lidar-derived AOT of 5\%-20\% (Mattis et al., 2004).

The basic idea of our lidar-photometer method is to use the depolarization ratio measured with lidar for the identification of layers with non-spherical particles and to quantify their contribution to the lidar-derived profile of the particle backscatter coefficient. This part of the data analysis is covered by steps 1-4 in Table 1. Volcanic and desert dust particles cause depolarization ratios $>0.3$ at $532 \mathrm{~nm}$, whereas spherical particles and fine-mode particles lead to depolarization ratios $<0.03$. The assumption that the fraction of lightdepolarizing, non-spherical particles is almost identical with the coarse-particle fraction is of fundamental importance in the retrieval. According to this assumption, the coarse-mode AOT derived from the photometer observations is dominated by light extinction by non-spherical particles and the derived coarse-mode particle volume concentration describes the volume concentration of non-spherical particles. Consequently, we assume that the spherical-particle fraction, which does not depolarize laser light during the $180^{\circ}$ scattering 
Table 1. The seven steps of the PMAP-POLIPHON retrieval scheme to obtain profiles of coarse and fine particle mass concentrations from polarization lidar observations (with support from sun-sky photometry, step 6). Indices v, t, c, and f denote volume (molecules plus particles), total (fine plus coarse mode), coarse mode, and fine mode, respectively. The methods applied in the different steps are described in the respective references.

\begin{tabular}{llll}
\hline Step & Computed parameter & & References \\
\hline 1 & Volume linear depolarization ratio & $\delta_{\mathrm{V}}$ & Freudenthaler et al. (2009) \\
2 & Particle backscatter coefficient & $\beta_{\mathrm{t}}$ & Ansmann and Müller (2005) \\
3 & Particle linear depolarization ratio & $\delta_{\mathrm{t}}$ & Tesche et al. (2009b) \\
4 & Coarse and fine-mode backscatter coefficients & $\beta_{\mathrm{c}}, \beta_{\mathrm{f}}$ & Tesche et al. (2009b) \\
5 & Coarse and fine-mode extinction coefficients & $\sigma_{\mathrm{c}}, \sigma_{\mathrm{f}}$ & Tesche et al. (2009b); Ansmann et al. (2011b) \\
6 & Coarse and fine-mode volume-to-extinction ratios & $v_{\mathrm{c}} / \tau_{\mathrm{c}}, v_{\mathrm{f}} / \tau_{\mathrm{f}}$ & Ansmann et al. (2011b) \\
7 & Coarse and fine particle mass concentrations & $m_{\mathrm{c}}, m_{\mathrm{f}}$ & Ansmann et al. (2011b) \\
\hline
\end{tabular}

process, is almost identical with the fine-mode particle fraction and is thus responsible for the fine-mode AOT. The approach ignores therefore backscatter contributions of small non-spherical particles to the fine-mode backscatter coefficient, and backscatter contributions of large spherical particles are misinterpreted as fine-mode-related backscatter.

Our field campaign experience of combined lidarphotometer observations shows that our basic assumption holds well for continental aerosols, e.g., for mixtures of desert dust and biomass-burning smoke (Tesche et al., 2009b, $2011 \mathrm{~b}$ ) or mixtures of volcanic dust and urban haze (Ansmann et al., 2011b). Obviously non-spherical fine-mode particles and spherical coarse-mode particles are of minor importance in cases of continental aerosol mixtures and do not significantly contribute to the measured optical effects.

The method does not work in cases with significant contributions of wet marine particles to the observed particle optical properties. Marine coarse-mode particles are spherical at high relative humidities so that their depolarization ratio is close to zero (Murayama et al., 1999; Sakai et al., 2010; Groß et al., 2011b). This fraction of particles would thus be interpreted as fine-mode aerosol. On the other hand, at relative humidities $<50 \%$ sea salt particles crystalize, loose their spherical shape, and cause significant depolarization ratios of up to $10 \%$ (Murayama et al., 1999; Sakai et al., 2010). The presence of wet and dry fine-and coarse-mode marine particles thus may considerably disturb the data analysis (separation of fine and coarse mode) and may thus introduce large uncertainties in the derived aerosol mass concentrations.

Furthermore, in our data analysis we have to assume an externally mixed aerosol which contains only one type of coarse-mode particles (desert dust or volcanic dust). In order to retrieve the mass concentration of desert dust we must be sure that the influence of marine and volcanic particles on the measured optical properties is negligible. Vice versa, in the estimation of volcanic particle mass concentrations we have to assume that interference by desert dust and marine particles can be ignored. This assumption was, for example, not fulfilled in the case of Eyjafjallajökull volcanic measurements over southeastern Europe in April and May 2010 (Pa- payannis et al., 2012). Volcanic dust and desert dust occurred simultaneously in lofted plumes and contributed to the observed coarse-mode fraction.

Steps 1-3 of our retrieval (see Table 1) are straightforward and well-established lidar methods. In step 4, the backscatter contributions of the non or weakly light-depolarizing particles (e.g., urban haze and biomass-burning smoke) and the strongly light-depolarizing particles (e.g., volcanic or desert dust) are separated. Here, we have to assume characteristic particle depolarization ratios for desert dust and volcanic dust. For desert dust, we use a value of $0.31 \pm 0.04$ (Freudenthaler et al., 2009; Groß et al., 2011b), for volcanic dust $0.34 \pm 0.04$ (Ansmann et al., 2010; Wiegner et al., 2012; Groß et al., 2012), and for fine-mode and wet marine particles $0.02 \pm 0.02$ (Groß et al., 2011b).

The assumptions regarding the dust depolarization ratio are of crucial importance for the entire retrieval scheme. The linear depolarization ratio of desert dust particles decreases with particle size and thus can change via sedimentation processes during long range transport. According to the laboratory study of Sakai et al. (2010), the particle depolarization ratio may decrease from values around 0.4 for size distributions of mineral dust with a high number of supermicrometer particles (e.g., at sites close to the dust source) to values of 0.15 in remote areas after the removal of a significant fraction of the large particles by sedimentation during long-range transport. However such a decrease of the depolarization ratio has not been observed. Lidar measurements close to the Saharan dust source (Freudenthaler et al., 2009) and after long-range transport towards Europe (Wiegner et al., 2011) and Cape Verde (Tesche et al., 2011a) show similar values from 0.3-0.35 in lofted dust-dominated aerosol layers. After long-range transport of mineral dust from desert regions in western and northern China, particle depolarization ratios in layers dominated by dust were also found in the range of $0.3-$ 0.35 over Japan (Sakai et al., 2003a; Murayama et al., 2003; Sugimoto et al., 2003; Shimizu et al., 2004). Lidar observations at Barbados (about $4000 \mathrm{~km}$ west of Cape Verde, and $5000-7000 \mathrm{~km}$ apart from the main Saharan dust sources) indeed indicate a decrease of the particle depolarization ratio 
towards $0.22-0.3$ (Ilya Serikov, personnel communication, 2012). However, it remains unclear whether this effect is caused by (a) sedimentation and removal of large dust particles, (b) mixing of desert dust particles with wet, weakly depolarizing marine particles, and/or (c) contamination (coating) of dust particles with hygroscopic material as result of particle aging through cloud processing. Coating effects may lead to a change in the dust particle shape characteristics and thus a lowering of the depolarization ratio. But such coating effects remain to be clearly identified in laboratory studies or field observations (Sakai et al., 2003b). The consistency between the lidar and photometer observations in dense plumes of desert dust mixed with biomass burning smoke over Praia, Cape Verde, in January 2008 (Tesche et al., 2009b) do not indicate an impact of coating effects on the shape characteristics of coarse-mode particles. Therefore, we assume that the applied particle depolarization ratio of $0.31 \pm 0.04$ well represents the range of typical desert dust depolarization ratios close to the dust sources as well as at remote sites.

Concerning the depolarization ratio of volcanic dust, several observations of the Eyjafjallajökull volcanic dust indicate values from $0.34 \pm 0.03$ to $0.38 \pm 0.03$ (Groß et al., 2012; Chazette et al., 2012a,b; Miffre et al., 2012; Winker et al., 2012). Therefore, we assume that a value of $0.34 \pm 0.04$ is representative for young as well as aged volcanic dust particles. Here coating effects play a significant a role when the relative humidity is high and water up take by the hydrophilic volcanic dust particles takes place, This aspect is discussed in Sect. 3.4.

In step 5 of the retrieval after Table 1, we estimate the profiles of the volume extinction coefficients $\sigma_{\mathrm{f}}$ and $\sigma_{\mathrm{c}}$ for fine and coarse mode by multiplying the fine and coarse particle backscatter coefficients $\beta_{\mathrm{f}}$ and $\beta_{\mathrm{c}}$ with respective fine and coarse particle lidar ratios. Raman lidar observations indicate lidar ratios from 45 to $65 \mathrm{sr}$ for desert dust and volcanic dust. The values accumulate between 50 and $60 \mathrm{sr}$ (Tesche et al., 2009a; Ansmann et al., 2010; Groß et al., 2011b, 2012; Wiegner et al., 2011). The range of values for the fine-mode particle lidar ratio is much larger. Urban haze particles show values from 30 to $80 \mathrm{sr}$ (Müller et al., 2007). Lidar ratios of absorbing biomass-burning smoke may often exceed $100 \mathrm{sr}$ (Ansmann et al., 2000; Franke et al., 2003; Tesche et al., 2011b). Consequently, it is advisable to use the actual lidar and photometer observations to estimate the most appropriate fine-mode lidar ratio. This fine-mode lidar ratio is obtained from the ratio of the fine-mode AOT (from photometer observations) and the vertically integrated backscatter coefficient for non-depolarizing particles (from the lidar observations.) This point is further discussed in Sect. 3.

In step 7 of the retrieval (step 6 is explained afterwards), the mass concentrations $m_{\mathrm{f}}$ and $m_{\mathrm{c}}$ of fine-mode and coarsemode particles, respectively, are estimated by using the lidarderived particle extinction coefficients $\sigma_{\mathrm{f}}$ and $\sigma_{\mathrm{c}}$ : $m_{\mathrm{f}}=\frac{\sigma_{\mathrm{f}}}{k_{\mathrm{ext}, \mathrm{f}}}$,

$m_{\mathrm{c}}=\frac{\sigma_{\mathrm{c}}}{k_{\mathrm{ext}, \mathrm{c}}}$.

$k_{\text {ext,f }}=\sigma_{\text {ext,ff }} /\left(\rho_{\mathrm{f}} V_{\mathrm{f}}\right)$ and $k_{\text {ext, }}=\sigma_{\text {ext, }} /\left(\rho_{\mathrm{c}} V_{\mathrm{c}}\right)$ are the massspecific extinction coefficients for fine mode and coarse mode, respectively. $\sigma_{\text {ext,f }}$ and $\sigma_{\text {ext,c }}$ denote the volume extinction coefficients that belong to the respective particle mass densities $\rho_{\mathrm{f}} V_{\mathrm{f}}$ and $\rho_{\mathrm{c}} V_{\mathrm{c}} . \rho$ and $V$ are particle density and particle volume concentration, respectively. We use $\rho_{\mathrm{c}}$ of $2.6 \mathrm{~g} \mathrm{~cm}^{-3}$ for desert dust (Hess et al., 1998; Gasteiger et al., 2011) and volcanic dust particles (Ansmann et al., 2011b). For fine-mode particles, we assume $\rho_{\mathrm{f}}$ of $1.5-1.6 \mathrm{~g} \mathrm{~cm}^{-3}$ (Cozic et al., 2008; Bukowiecki et al., 2011) for central European haze and for the sulfate aerosol which formed from the volcanic $\mathrm{SO}_{2}$ emissions. These values of $\rho_{\mathrm{f}}$ consider a variable liquid water content of the mostly sulfate-containing particles (ammonium sulfate) (Hess et al., 1998; Tang and Munkelwitz, 1994). In the analysis of a mixed aerosol plume containing desert dust and biomass-burning smoke in section 3 , we use $\rho_{\mathrm{f}}$ of $1.35 \mathrm{~g} \mathrm{~cm}^{-3}$ for the biomass-burning particles (Reid et al., 2005).

Because the ratios $\sigma_{\text {ext,f }} / V_{\mathrm{f}}$ and $\sigma_{\text {ext,c }} / V_{\mathrm{c}}$ (i.e., $k_{\mathrm{ext}, \mathrm{f}} \rho_{\mathrm{f}}$ and $k_{\mathrm{ext}, \mathrm{c}} \rho_{\mathrm{c}}$ ) can vary considerably as a function of particle size distribution (see Table 2 , column for $1 / k_{\text {ext }} \rho$ ), actual estimates of these ratios are required in the data analysis. As proxies for $\sigma_{\mathrm{ext}, \mathrm{f}} / V_{\mathrm{f}}$ and $\sigma_{\mathrm{ext}, \mathrm{c}} / V_{\mathrm{c}}$ we use the AERONET observations of the ratio of AOT $\tau_{\mathrm{f}}$ to the column-integrated volume concentration $v_{\mathrm{f}}$ for the fine mode and the respective observed ratio $\tau_{\mathrm{c}} / v_{\mathrm{c}}$ for the coarse mode. Equations (1) and (2) can then be written as (Ansmann et al., 2011b)

$m_{\mathrm{f}}=\rho_{\mathrm{f}}\left(\overline{v_{\mathrm{f}} / \tau_{\mathrm{f}}}\right) \sigma_{\mathrm{f}}$,

$m_{\mathrm{c}}=\rho_{\mathrm{c}}\left(\overline{v_{\mathrm{c}} / \tau_{\mathrm{c}}}\right) \sigma_{\mathrm{c}}$.

$\overline{v / \tau}$ denotes the temporal mean value of individual values of $v / \tau$ observed within a given time period. Time series of observed values of $v_{\mathrm{f}} / \tau_{\mathrm{f}}$ and $v_{\mathrm{c}} / \tau_{\mathrm{c}}$ for the desert dust and volcanic dust events discussed in Sect. 3 are presented in Fig. 1.

The comparably weak variability in the Saharan dust $v_{\mathrm{c}} / \tau_{\mathrm{c}}$ ratios in Fig. 1 (cases a and b) found at sites close to the source as well as at remote locations and the likewise strong changes in the volcanic $v_{\mathrm{c}} / \tau_{\mathrm{c}}$ ratio (case c versus cases $\mathrm{d}-$ f) motivated us to review the recent literature concerning observed and modeled mass-specific extinction coefficients for desert dust and volcanic dust and to re-analyze own AERONET sun-sky photometer observations performed during strong Saharan dust outbreaks at Leipzig in October 2001 (Ansmann et al., 2003; Müller et al., 2003) and May 2008 (Wiegner et al., 2011) and during the SAMUM-1 (close to the desert dust source region) and SAMUM-2 campaigns (long-range transport regime). Table 2 provides an overview of this effort. Only Saharan dust observations are considered, for which the contamination with anthropogenic finemode particles should be very small. Nevertheless, sources 
Table 2. Overview of recently observed mass-specific extinction coefficients $k_{\text {ext }}=\sigma_{\text {ext }} /(\rho V)$ for volcanic and desert dust aerosols. In addition the ratio of frequently measured volume concentration to volume extinction coefficient $V / \sigma_{\text {ext }}=1 /\left(k_{\text {ext }} \rho\right)$ is given. A few modeled values (Hess et al., 1998; Barnaba and Gobbi, 2004) for coarse-mode as well as for fine-mode particles are added. Values are taken from the indicated literature (reference). Saharan dust mass-specific extinction coefficients (mean values for the vertical tropospheric column) computed from AERONET sun-sky photometer observations at Leipzig, Germany, Ouarzazate, Morocco, and Praia, Cape Verde, are included (indicated by: this study). The mass-specific extinction coefficients hold for a coarse-mode particle density of $\rho_{\mathrm{c}}=2.6 \mathrm{~g} \mathrm{~cm}{ }^{-3}$ (desert and volcanic dust), fine-mode particle density of $\rho_{\mathrm{f}}=1.6 \mathrm{~g} \mathrm{~cm}^{-3}$, and particle extinction coefficients for the $500-550 \mathrm{~nm}$ wavelength range. Mean values and/or the range of observed values are given. Hervo et al. (2012) derived mass-specific extinction coefficients for volcanic dust without assumptions of particle mass density.

\begin{tabular}{|c|c|c|c|}
\hline Reference & $\begin{array}{c}k_{\mathrm{ext}} \\
{\left[\mathrm{m}^{2} \mathrm{~g}^{-1}\right]}\end{array}$ & $\begin{array}{l}1 /\left(k_{\operatorname{ext}} \rho\right) \\
{\left[10^{-6} \mathrm{~m}\right]}\end{array}$ & Comment \\
\hline \multicolumn{4}{|c|}{ Eyjafjallajökull volcanic dust, April-May 2010} \\
\hline Johnson et al. (2012) & $\begin{array}{c}0.40-0.95 \\
0.53\end{array}$ & $\begin{array}{l}0.96-0.40 \\
0.72\end{array}$ & $\begin{array}{l}\text { Airborne, in situ, near volcanic source, North Sea } \\
>1000 \mathrm{~km} \text { distance from source, North Sea, UK }\end{array}$ \\
\hline Marenco et al. (2011) & $0.53-0.80$ & $0.72-0.48$ & Airborne, in situ, comparison with lidar, North Sea, UK \\
\hline Turnbull et al. (2012) & $0.53-0.71$ & $0.72-0.54$ & Airborne, in situ, North Sea \\
\hline Hervo et al. (2012) & 0.64 & 0.60 & Ground-based, in situ, $1.5 \mathrm{~km}$ height, France \\
\hline Gasteiger et al. (2011) & $0.69(0.43-1.11)$ & $0.56(0.89-0.35)$ & Scattering model, multi- $\lambda$ lidar, photometer, Germany \\
\hline Miffre et al. (2012) & $0.69 \pm 0.10$ & $0.56 \pm 0.09$ & Scattering model, lidar, France \\
\hline Ansmann et al. (2010) & 0.51 & 0.75 & $\begin{array}{l}\text { AERONET, remote sensing, first ash front (16 April), very } \\
\text { large particles, central Germany }\end{array}$ \\
\hline Devenish et al. (2012) & 0.53 & 0.72 & $\begin{array}{l}\text { AERONET, remote sensing, first ash front (16 April), very } \\
\text { large particles, southern UK }\end{array}$ \\
\hline Ansmann et al. (2011b) & $0.64 \pm 0.10$ & $0.60 \pm 0.10$ & AERONET, remote sensing, Germany \\
\hline Sicard et al. (2012) & $0.38-0.43$ & $1.00-0.89$ & AERONET, remote sensing, Spain \\
\hline \multicolumn{4}{|c|}{ Grimsvötn volcanic dust, May 2011} \\
\hline This study & $0.43 \pm 0.05$ & $0.90 \pm 0.05$ & AERONET, remote sensing, Germany \\
\hline \multicolumn{4}{|l|}{ Saharan dust } \\
\hline Hess et al. (1998) & 0.64 & 0.60 & OPAC model \\
\hline Hess et al. (1998) & 0.37 & 1.03 & OPAC model, transported dust, free troposphere \\
\hline Barnaba and Gobbi (2004) & $0.54-1.50$ & $0.71-0.26$ & Modeling study, full range of realistic size distributions \\
\hline Johnson and Osborne (2011) & $0.48 \pm 0.10$ & $0.80 \pm 0.20$ & GERBILS, airborne, in situ, western and west of Africa \\
\hline Osborne et al. (2008) & $0.30-0.40$ & $1.29-0.96$ & DABEX, DODO1, airborne, in situ, western Africa \\
\hline Weinzierl et al. (2009) & $0.45-0.70$ & $0.85-0.55$ & SAMUM-1, airborne, in situ, South Morocco, $>2 \mathrm{~km}$ height \\
\hline Müller et al. (2012) & $0.57 \pm 0.04$ & $0.68 \pm 0.05$ & SAMUM-1, multi- $\lambda$ lidar, South Morocco, $>2 \mathrm{~km}$ height \\
\hline This study & $0.50 \pm 0.05$ & $0.77 \pm 0.07$ & AERONET, remote sensing, Germany, Oct 2001, May 2008 \\
\hline This study & $0.52 \pm 0.03$ & $0.74 \pm 0.04$ & SAMUM-1, AERONET, remote sensing, South Morocco \\
\hline This study & $0.52 \pm 0.06$ & $0.74 \pm 0.08$ & SAMUM-2, AERONET, remote sensing, Cape Verde \\
\hline \multicolumn{4}{|l|}{ Continental particles (fine mode) } \\
\hline Hess et al. (1998) & $1.80(2.40)$ & $0.35(0.26)$ & OPAC model, clean continental, rel. humidity $50 \%$ (80\%) \\
\hline Hess et al. (1998) & $2.20(2.90)$ & $0.28(0.22)$ & OPAC model, polluted continental, rel. humidity $50 \%(80 \%)$ \\
\hline Barnaba and Gobbi (2004) & $3.50 \pm 0.1$ & $0.18 \pm 0.005$ & Modeling study, full range of realistic size distributions \\
\hline Ansmann et al. (2011b) & $3.50 \pm 0.4$ & $0.18 \pm 0.02$ & AERONET, remote sensing, Germany \\
\hline Sicard et al. (2012) & $2.40 \pm 0.1$ & $0.25 \pm 0.01$ & AERONET, remote sensing, Spain \\
\hline
\end{tabular}

of uncertainties remain. Airborne in-situ observations may suffer from high uncertainties in the retrieval of the entire particle size spectrum and the subsequent retrieval of the coarse-mode particle volume concentration. As a consequence, we used the SAMUM-1 PM $_{2.5}$ (particles with diameters $<2.5 \mu \mathrm{m}$ ) observations of Weinzierl et al. (2009) in Table 2 instead of the results for the entire size distribution and multiplied the respective $\mathrm{PM}_{2.5}$ volume concentration by a factor of 3.1 to estimate the total volume concentration (as considered in Table 2). This factor of 3.1 for the ratio of the total to $\mathrm{PM}_{2.5}$ volume concentration of desert dust particles was derived from ground-based SAMUM-1 and SAMUM-2 observations (Kandler et al., 2009, 2011). 


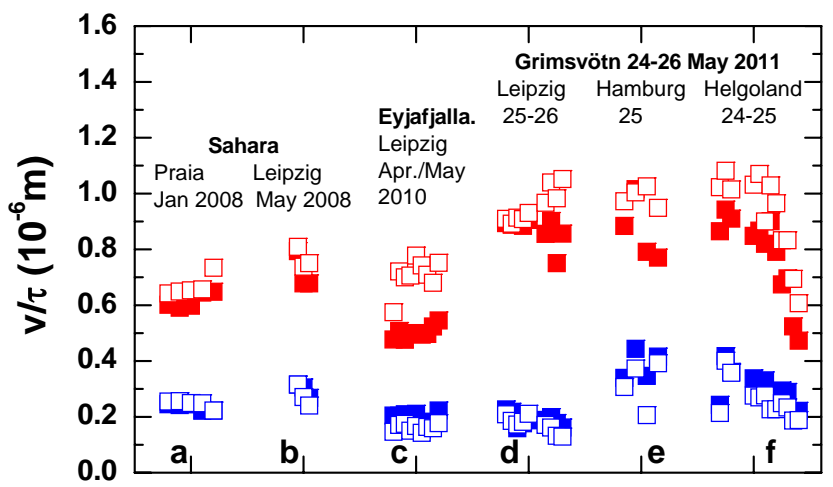

Fig. 1. Ratio $v / \tau$ of column volume concentration $v$ to AOT $\tau$ at $532 \mathrm{~nm}$ for coarse (red) and fine particles (blue). The ratios are derived from AERONET sun-sky photometer measurements in (a) mixed desert-dust/biomass-burning-smoke plumes at Praia, Cape Verde in January 2008, (b) during a strong Saharan dust outbreak at Leipzig in May 2008, (c) during the Eyjafjallajökull event (Leipzig, April-May 2010), and (d-f) the Grimsvötn volcanic dust episode (Helgoland, Hamburg, Leipzig, May 2011). Fine-mode and coarsemode $\tau$ values were calculated by using the Dubovik approach (open symbols) and the O'Neill method (closed symbols). See text for more details.

As can be seen in Table 2, the observed Saharan dust $k_{\text {ext }}$ values accumulate between 0.45 and $0.65 \mathrm{~m}^{2} \mathrm{~g}^{-1}$ disregarding the distance of the observation from the source, whereas the values for volcanic dust are more equally distributed from 0.4 to 1.0. All values, except the ones from the study of Hervo et al. (2012), are based on the assumption of a coarse-particle mass density of $2.6 \mathrm{~g} \mathrm{~m}^{-3}$. Hervo et al. (2012) derived values without the need for an assumption on particle mass density. However, they derived the specific extinction coefficients for the wavelength of $355 \mathrm{~nm}$. In Table 2, we assume that these values still hold for 500-550 nm (i.e., we assume no wavelength-dependence of the extinction coefficient and AOT for coarse particles). The model results of Barnaba and Gobbi (2004) show a likewise large range of potential dust values. The detailed study of the relationships between particle backscatter, extinction, surface area, and volume concentrations for various aerosol types can be found in Barnaba and Gobbi (2001, 2002). These relationships have been successfully validated in 2003 (Gobbi et al., 2003) by comparing polarization lidar and in situ measurements, and the mineral dust volume (or mass) concentration could be estimated from backscatter observations with acceptable accuracy.

Volcanic particle size distributions seem to vary strongly depending on the distance to the source and eruption type (explosive, less explosive, ice-capped explosion or not). The significant difference between coarse-mode $v_{\mathrm{c}} / \tau_{\mathrm{c}}$ values after the Eyjafjallajökull and Grimsvötn volcanic eruptions in Fig. 1 corroborate this hypothesis. The larger the particles the larger the ratio $v_{\mathrm{c}} / \tau_{\mathrm{c}}$, and the lower the mass-specific extinc- tion coefficient (provided the mass density of the volcanic dust particles is similar for both volcanic events).

Even for fine particles (urban haze, biomass-burning smoke, fresh and aged sulfate aerosol originating from volcanic $\mathrm{SO}_{2}$ emissions) the $v_{\mathrm{f}} / \tau_{\mathrm{f}}$ values can vary within a factor of two (see Table 2 and Fig. 1, Helgoland and Hamburg versus Leipzig values). The model simulations by Barnaba and Gobbi (2004) in Table 2 with $k_{\text {ext,f }}$ values close to $3.5 \mathrm{~m}^{2} \mathrm{~g}^{-1}$ considering the full range of realistic size distributions of aged fine-mode European haze do not show this variability. In accordance with the model results, the values of $v_{\mathrm{f}} / \tau_{\mathrm{f}}$ observed over Leipzig (in urban air, less affected by soil dust, and taken far away from marine environments) also show relatively constant values around $3.5 \mathrm{~m}^{2} \mathrm{~g}^{-1}$.

The spread of the $k_{\text {ext }}$ values in Table 2 for a given aerosol type may provide an impression about the range of uncertainty in the particle mass retrieval after Eqs. (3) and (4) when using literature values in the data analysis. Our strategy is therefore to always check the actual values of $v_{\mathrm{f}} / \tau_{\mathrm{f}}$ and $v_{\mathrm{c}} / \tau_{\mathrm{c}}$ from sun-sky photometer observations performed side by side with the lidar observations.

A detailed discussion of uncertainties in the separation of the backscatter coefficient for fine-mode and coarse mode in Table 1 can be found in Tesche et al. (2009b, 2011b,c). Errors in the retrieval of mass concentrations after steps 1-7 are discussed by Ansmann et al. (2011b).

For well-detected desert or volcanic dust layers, as discussed in the next section, with uncertainties in the dustrelated backscatter coefficients of $10 \%-20 \%$ (mainly caused by the uncertainty in the assumptions of the dust and finemode depolarization ratios), with further uncertainties of $10 \%-15 \%$ in the successive conversion of backscatter into extinction coefficients caused by the lidar ratio estimate, $10 \%-25 \%$ in the dust mass density estimates, and $20 \%-$ $50 \%$ in the used $v / \tau$ ratio, the overall uncertainty in the dust mass concentration values is $30 \%-60 \%$. Slightly larger uncertainty values hold for the fine-mode particles in layers with pronounced fine-mode particle concentrations (boundary layer, lofted sulfate layers of volcanic origin). Here the higher uncertainty in the lidar ratio estimate is responsible for the larger overall uncertainty in the mass concentrations.

The uncertainties may exceed $100 \%$ in cases with very large dust particles (in dust outbreaks observed within 24$36 \mathrm{~h}$ after emission), as discussed by Ansmann et al. (2010, $2011 \mathrm{~b}$ ) because of large uncertainties in the $v / \tau$ ratio. The AERONET data analysis scheme assumes particles with radii $<15 \mu \mathrm{m}$ in the retrieval of the volume size distribution. If particles with larger sizes are present, the particle volume concentration, the $v / \tau$ ratio, and the dust mass concentration are largely underestimated. 


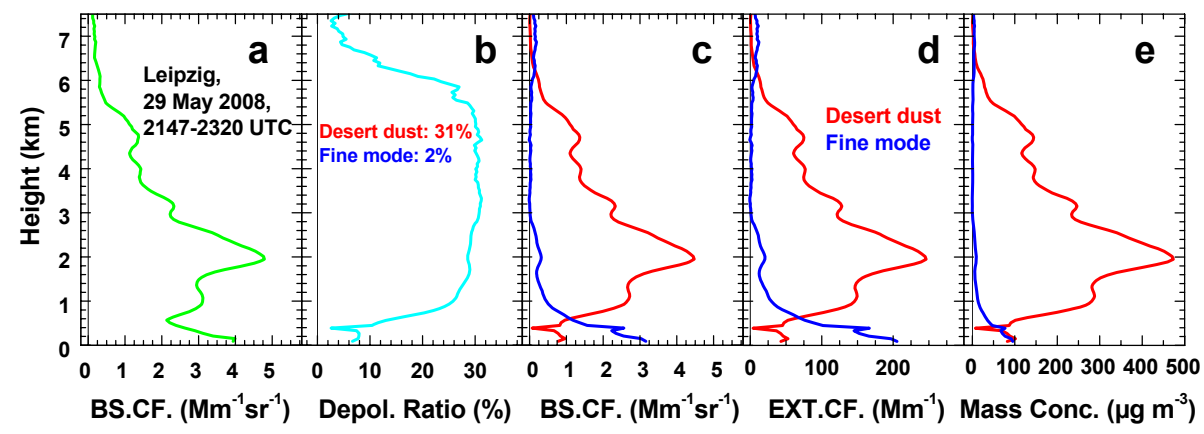

Fig. 2. (a) $532 \mathrm{~nm}$ particle backscatter coefficient, (b) $532 \mathrm{~nm}$ particle linear depolarization ratio, (c) fine-mode (blue) and coarse-mode (red) particle backscatter coefficients, (d) fine-mode (blue) and coarse-mode (red) particle extinction coefficients, (e) and fine-mode (blue) and coarse-mode (red) particle mass concentrations. The lidar observations were taken at Leipzig (120 m above sea level, a.s.1.) in May 2008.

\section{Measurement examples}

We present four measurement cases. Two cases deal with Saharan dust. The third and fourth examples show volcanic aerosol measurements. For the first time, comparisons of lidar-photometer observations of Eyjafjallajökull volcanic aerosols (eruptions in April 2010) and Grimsvötn volcanic aerosols (eruptions in May 2011) are shown.

\subsection{Saharan dust above urban haze}

The retrieved particle properties of a strong Saharan dust outbreak towards central Europe are shown in Fig. 2. This outbreak is also discussed in detail by Wiegner et al. (2011) based on Munich Raman lidar observations about $400 \mathrm{~km}$ south of Leipzig. A clear separation of the aerosol in the boundary layer (reaching to $500 \mathrm{~m}$ height) from the aerosol in the lofted Saharan dust layer (extending from 500 to $6500 \mathrm{~m}$ height) was observed over Leipzig on 29 May 2008.

The height profile of the total particle backscatter coefficient in Fig. 2a (retrieval step 2 after Table 1) was determined by means of the Raman lidar method (Ansmann et al., 1992). This method could be used in all four cases shown in this section. The technique provides most accurate solutions for the backscatter coefficient down to very low heights (if the lidar is well adjusted as is the case here) because the method makes use of signal ratios so that the overlap effect in the near-range of the lidar widely cancels out.

By assuming particle depolarization ratios of 0.31 and 0.02 for Saharan dust and anthropogenic haze, respectively, we separated the particle backscatter coefficients for coarse mode and fine mode (retrieval step 4 after Table 1). It can be seen in Fig. $2 c$ that traces of anthropogenic particles or other spherical fine-mode particles are present in the lower part of the dust plume up to $3 \mathrm{~km}$ height, probably caused by upward mixing of polluted air during the transport over northern Africa, the Mediterranean, and southern Europe.

In the conversion of the backscatter profiles into extinction profiles (retrieval step 5) we assumed a volcanic-dust lidar ra- tio of $55 \mathrm{sr}$ and a fine-mode lidar ratio of $65 \mathrm{sr}$ in good agreement with the photometer-derived AOT value (see discussion below). The profiles of the particle extinction coefficients for fine and coarse mode are shown in Fig. 2d.

The particle mass concentrations for desert dust and the fine-mode particle fraction are computed by using the information shown in Fig. 1 (case b, retrieval step 6). With $\rho_{\mathrm{c}}=$ $2.6 \mathrm{~g} \mathrm{~cm}^{-3}, \rho_{\mathrm{f}}=1.6 \mathrm{~g} \mathrm{~cm}^{-3}$, and mean values of $v_{\mathrm{c}} / \tau_{\mathrm{c}}=$ $0.74 \times 10^{-6} \mathrm{~m}$ and $v_{\mathrm{f}} / \tau_{\mathrm{f}}=0.29 \times 10^{-6} \mathrm{~m}$ we obtain massspecific extinction coefficients of $k_{\mathrm{ext}, \mathrm{c}}=0.52 \mathrm{~m}^{2} \mathrm{~g}^{-1}$ and $k_{\text {ext, } \mathrm{f}}=2.19 \mathrm{~m}^{2} \mathrm{~g}^{-1}$ for the coarse and fine mode, respectively. By using these numbers in the conversion of the extinction coefficients into mass concentrations after Eqs. (3) and (4) we end up with the mass profiles in Fig. 2e (retrieval step 7).

As can be seen in Fig. 2e desert dust mass concentrations of up to $300-500 \mu \mathrm{g} \mathrm{m}^{-3}$ were observed in the late evening of 29 May 2008. The fine-mode mass concentration reached values of $100 \mu \mathrm{g} \mathrm{m}^{-3}$ close to the surface, decreased with height, and was found to be almost zero at heights above $1 \mathrm{~km}$. On days with Saharan dust we frequently observe a strong or even a complete suppression of the evolution of a convective boundary layer which is usually as deep as 1.5$2.5 \mathrm{~km}$ on sunny days end of May. The anthropogenic haze layer, in which the pollution accumulates over days and remains trapped, is then rather shallow with depths $<1 \mathrm{~km}$.

The uncertainties in the retrieved mass concentrations shown in Fig. 2 are as follows: the coarse-mode backscatter coefficients in the lofted dust plume at heights $>700 \mathrm{~m}$ are obtained with an uncertainty of around $10 \%$. As mentioned above, this uncertainty is mainly caused by the assumption of the desert dust depolarization ratio of 0.31 with an uncertainty of \pm 0.04 and of the fine-mode depolarization ratio of 0.02 with an uncertainty of \pm 0.02 . Taking comparably small uncertainties of $10 \%$ in the well-known mineral dust lidar ratios into account, a $15 \%$ uncertainty in the estimated mineral dust particle density, and a $20 \%$ uncertainty in the observed, and thus relatively well-known $v_{\mathrm{c}} / \tau_{\mathrm{c}}$ conversion factors into account, we obtain overall uncertainties in the 
Table 3. Aerosol optical thickness (AOT), column-integrated backscatter coefficient $\left(\mathrm{CB}\right.$ in sr ${ }^{-1}$ ), and column lidar ratio (AOT/CB in sr) for the four case studies shown in Figs. 2-5. All values are given for $532 \mathrm{~nm}$ wavelength. Ångström exponents (AE) after O'Neill et al. (2003) for the spectral range around $500 \mathrm{~nm}$ are shown in addition. The $532 \mathrm{~nm}$ AOTs are obtained from the measured $500 \mathrm{~nm}$ AOTs by means of the respective Ångström exponents (AE). The coarse-mode AE is set to zero in the photometer data analysis (O'Neill et al., 2003). AERONET level 2.0 data are used, except for 22 January 2008 (level 1.0).

\begin{tabular}{llllcc}
\hline Case study, observation times, location & Aerosol & AOT & CB & AOT/CB & AE \\
\hline Saharan dust/urban haze, & total & 0.770 & 0.01414 & 54.4 & 0.29 \\
AOT (17:22 UTC), CB (21:47-23:20 UTC), & fine & 0.162 & 0.00253 & 64.1 & 1.49 \\
Leipzig, 29 May 2008 & coarse & 0.608 & 0.01161 & 52.4 & 0 \\
\hline Saharan dust/smoke/marine, & total & 0.301 & 0.00536 & 56.2 & 0.47 \\
AOT (18:32-18:37 UTC), CB (20:05-21:00 UTC), & smoke & 0.107 & 0.00109 & 98.2 & 1.48 \\
Praia, 22 January 2008 & coarse & 0.194 & 0.00427 & 45.4 & 0 \\
& dust & 0.182 & 0.00352 & 51.7 & 0 \\
\hline Volcanic dust/sulfate/urban haze, & total & 0.649 & 0.01369 & 47.4 & 1.12 \\
AOT (14:38-15:37 UTC), CB (14:35-15:36 UTC), & fine & 0.506 & 0.01135 & 44.6 & 1.45 \\
Leipzig, 19 April 2010 & coarse & 0.143 & 0.00261 & 54.8 & 0 \\
\hline Volcanic dust/sulfate/urban haze, & total & 0.130 & 0.00376 & 34.6 & 1.19 \\
AOT (09:53-11:53 UTC), CB (10:00-11:50 UTC), & fine & 0.055 & 0.00248 & 22.2 & 2.72 \\
Leipzig, 25 May 2011 & coarse & 0.075 & 0.00128 & 58.6 & 0 \\
\hline
\end{tabular}

dust mass concentrations in the lofted mineral dust plume of about $30 \%$. For the boundary layer, the mass concentration errors are higher with values from $35 \%-55 \%$. For the fine-mode, the backscatter coefficient uncertainty is around $15 \%$ in the boundary layer and increases rapidly with height above $700 \mathrm{~m}$ up to values $>100 \%$. Together with realistic uncertainties in the fine-mode lidar ratio of $25 \%$, of $20 \%$ in the particle density, and of $20 \%$ in the observed $v_{\mathrm{f}} / \tau_{\mathrm{f}}$ conversion factor we obtain uncertainties around $40 \%$ for the fine-mode mass concentrations in the boundary layer.

In order to prove the overall consistency of the lidarphotometer observations and to check the validity of the assumption that the non-light-depolarizing particle fraction is almost identical with the fine-mode fraction and that the light-depolarizing particle fraction represents the coarse particle fraction, we compute the column-integrated backscatter coefficient $(\mathrm{CB})$ at $532 \mathrm{~nm}$ for the non-depolarizing particles (fine-mode CB in Table 3) and the light-depolarizing particle fraction (coarse-mode CB in Table 3) from the basic lidar data, i.e., from the fine-mode and coarse-mode backscatter profiles in Fig. 2c. Then we form the AOT/CB ratios by using the corresponding $532 \mathrm{~nm}$ AOTs for fine-mode and coarse mode obtained from the photometer observation. If the coarse-mode AOT/CB ratio shows typical values for desert dust (50-60 sr), we conclude that our basic retrieval assumption concerning large particles (coarse-mode particles $=$ non-spherical particles) is valid and thus the results are trustworthy. With other words, if the photometer-derived coarse-mode AOT is roughly equal with the lidar-derived AOT, which is well estimated by CB for non-spherical particles multiplied with $55 \mathrm{sr}$, then the basic assumption seems to be sufficiently valid in our coarse-mode mass retrieval. In a similar way we check the AOT/CB ratio for the small particles to proof the consistency of AOT and CB for fine-mode particles (spherical particle fraction).

As can be seen in Table 3, for the case of the strong Saharan dust outbreak, the fine-mode and coarse-mode-related AOTs were about 0.16 and 0.61 at $532 \mathrm{~nm}$, respectively, during one of the last sun-sky photometer measurements on 29 May 2008, 17:30 UTC, about $4 \mathrm{~h}$ before the lidar observations in Fig. 2 were performed. Very constant aerosol condition were given from the early morning of 28 May 2008 to the early morning of 30 May 2008. The total $500 \mathrm{~nm}$ AOT was always between $0.7-0.8$. Together with the lidar-derived column backscatter values CB for the non-depolarizing (fine mode) and depolarizing (coarse mode) particle fractions we obtain column lidar ratios of about $64 \mathrm{sr}$ (fine mode) and $52 \mathrm{sr}$ (coarse mode). These values are typical for anthropogenic, aged, moderately absorbing urban haze (Mattis et al., 2004; Müller et al., 2007) and for desert dust (Tesche et al., 2009a, 2011a; Groß et al., 2011b), respectively. This consistency of the lidar-photometer observations corroborates that the results in Fig. 2 are reliable. The estimated lidar ratios AOT/CB for fine-mode and coarse mode are used in the extinction profile computation (step 5 in Table 1, profiles in Fig. 2d).

\subsection{Saharan dust mixed with biomass-burning smoke}

During the SAMUM-2 campaign in the eastern tropical Atlantic in January and February 2008, lofted aerosol layers containing desert dust and biomass-burning smoke were frequently advected across the lidar site at Praia, Cape Verde (Groß et al., 2011b; Tesche et al., 2011a; Toledano et al., 2011). The aerosol stratification in Fig. 3 is typical for the 


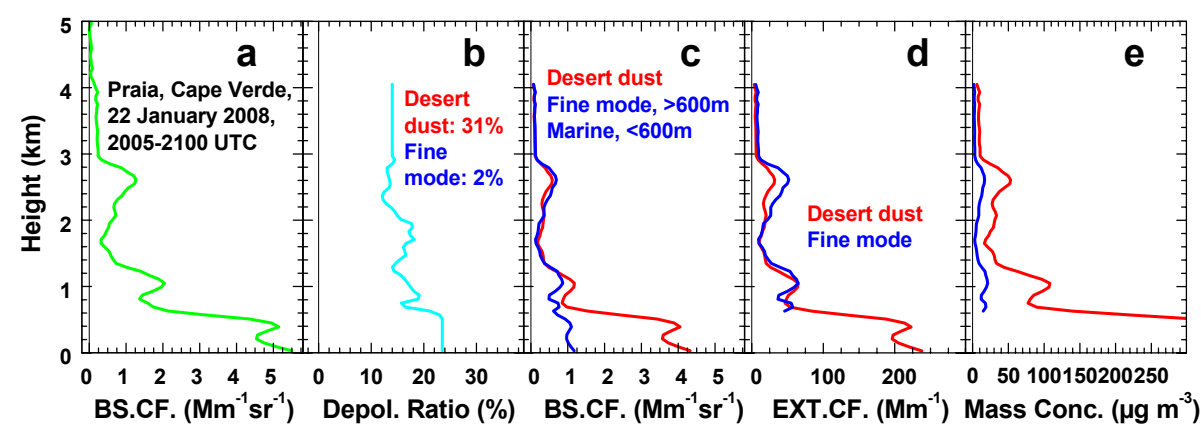

Fig. 3. Same as Fig. 2 except for a SAMUM-2 lidar observation at Praia ( $90 \mathrm{~m}$ a.s.1.), Cape Verde, in January 2008. Composite profiles of backscatter and extinction coefficients and linear depolarization ratio are shown, derived from measurements with three lidars (Groß et al., $2011 \mathrm{a}, \mathrm{b}$; Tesche et al., 2011a,b). In (c), $>600 \mathrm{~m}$ and $<600 \mathrm{~m}$ refer to the height range above and within the MBL with layer top height of $600 \mathrm{~m}$, respectively.

winter season over the eastern tropical North Atlantic (BenAmi et al., 2009). During the dry season in central Africa, a belt with strong fire activity extending over several thousands of kilometers from western to eastern Africa produces large amounts of fire smoke which is carried towards the Americas by dust-laden air (Ansmann et al., 2009; Ben-Ami et al., 2010; Baars et al., 2011).

The case, shown in Fig. 3, is discussed by Tesche et al. (2011a,b) and Groß et al. (2011a,b). Three ground-based SAMUM lidars contributed to Fig. 3. Two of them were optimized for near-range (marine boundary layer, MBL) observations and one for far-range measurements up to the tropopause $(<17 \mathrm{~km}$ height). By using a scanning polarization lidar (Groß et al., 2011b) it was possible to obtain accurate particle depolarization ratios with high vertical resolution down to very low heights within the MBL.

The profile of the total particle backscatter coefficient in Fig. 3a indicates strong backscattering within the MBL (top at about $600 \mathrm{~m}$ height) and moderate backscattering up to $4 \mathrm{~km}$ height. The particle depolarization ratio in Fig. $3 \mathrm{~b}$ shows values around $24 \%$ throughout the MBL caused by a strong contribution of desert dust to particle backscattering. Only $20 \%$ of MBL backscattering was caused by marine particles on this day, assuming wet marine particles producing a linear depolarization ratio of 0.02 (Groß et al., 2011b). If we keep in mind that the lidar ratios of wet marine particles and of mineral dust are $20 \mathrm{sr}$ and $55 \mathrm{sr}$, respectively, the marine extinction coefficients were about $20 \mathrm{Mm}^{-1}$ and the ones for desert dust particles $200-250 \mathrm{Mm}^{-1}$ (Fig. 3d), and therefore more than an order of magnitude higher than the marine values.

Accurate depolarization ratios were obtained up to $3 \mathrm{~km}$ height (Fig. 3b). Above that height we assumed a similar depolarization ratio up to the top of the smoke layer. Particle depolarization ratios from $10 \%-20 \%$ indicate a strong influence of smoke on the optical properties. The backscatter coefficients for fine and coarse mode in Fig. 3c corroborate the hypothesis. Above $1000 \mathrm{~m}$ height smoke and dust contributed almost equally to particle backscattering. However, the smoke extinction coefficients in Fig. 3d are slightly higher than the dust-related ones owing to the fact that the smoke lidar ratio was much larger than the dust lidar ratio. Lidar ratios of $55 \mathrm{sr}$ (desert dust, coarse mode) and $75 \mathrm{sr}$ (biomass-burning particles, fine mode) were used in the conversion of backscatter into extinction coefficients.

In the retrieval of the mass concentrations we used $\rho_{\mathrm{f}}=$ $1.35 \mathrm{~g} \mathrm{~cm}^{-3}$, and mean values of $v_{\mathrm{c}} / \tau_{\mathrm{c}}=0.64 \times 10^{-6} \mathrm{~m}$ and $v_{\mathrm{f}} / \tau_{\mathrm{f}}=0.24 \times 10^{-6} \mathrm{~m}$ (computed from the individual values in Fig. 1, case a). The respective fine-mode and coarse-mode-related mass-specific extinction coefficients are $k_{\text {ext }, \mathrm{c}}=0.60 \mathrm{~m}^{2} \mathrm{~g}^{-1}$ and $k_{\text {ext }, \mathrm{f}}=3.09 \mathrm{~m}^{2} \mathrm{~g}^{-1}$.

Because we cannot separate marine and smoke contributions to backscattering in the MBL (both aerosol types show low depolarization ratios), we provide particle mass concentration for the fine mode (smoke) for heights above the MBL in Fig. 3e only.

As can be seen in Fig. 3e, a mean of about $10 \mu \mathrm{g} \mathrm{m}^{-3}$ of smoke mass concentration was observed on that day with maximum values close to $20 \mu \mathrm{g} \mathrm{m}^{-3}$. Dust mass concentrations ranged from $300-400 \mu \mathrm{g} \mathrm{m}^{-3}$ in the MBL and from $25-100 \mu \mathrm{g} \mathrm{m}^{-3}$ in the free troposphere. We observed similar dust-smoke layers almost continuously during the SAMUM2 campaign from 15 January to 15 February 2008 (Tesche et al., 2011a,b). Smoke-related particle extinction coefficients ranged from $25-100 \mathrm{Mm}^{-1}$ between 1000 and $5000 \mathrm{~m}$ height during this period and indicated smoke particle mass concentrations of $10-35 \mu \mathrm{g} \mathrm{m}^{-3}$. It is interesting to note that Baars et al. (2011) found fine-mode-related extinction values of 10 $70 \mathrm{Mm}^{-1}$ in the Amazon rain forest north of Manaus, Brazil, during the wet season (February to May 2008) caused by long-range transport of African smoke. These extinction values indicate mass concentrations of African smoke particles of $5-20 \mu \mathrm{g} \mathrm{m}^{-3}$ over the Amazon rain forest. 


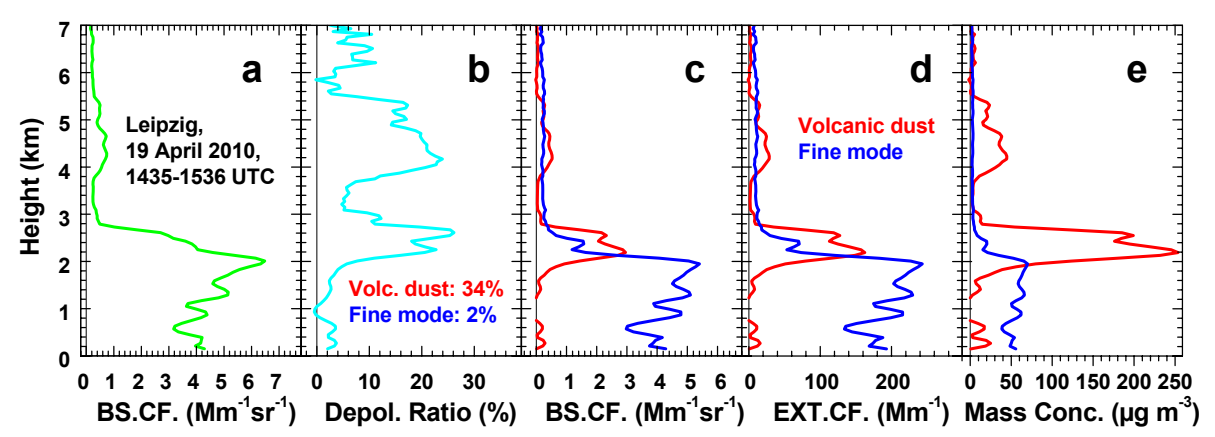

Fig. 4. Same as Fig. 2 except for Eyjafjallajökull volcanic aerosol observed at Leipzig in April 2010 (Ansmann et al., 2011b).

The question may arise why the layer with strong dust backscatter over Cape Verde coincides with the marine boundary layer. This results from very different air mass flows with winds from northeast in the boundary layer and from southerly direction within the smoke-containing air above $600 \mathrm{~m}$ height (Engelmann et al., 2011).

The uncertainties in the dust backscatter coefficients for heights $<600 \mathrm{~m}$ are $10 \%$ and $10 \%-15 \%$ in the lofted mixed dust-smoke layer. By further assuming an uncertainty in the dust lidar ratios of $10 \%$, of $15 \%$ in the estimated mineral dust density, and of $20 \%$ in the $v_{\mathrm{c}} / \tau_{\mathrm{c}}$ conversion values, we end up with an overall uncertainty in the mass concentrations of mineral dust of about $30 \%$ in the mixed layer above $600 \mathrm{~m}$. For the fine-mode, the backscatter coefficient uncertainty is about $10 \%-15 \%$ in the lofted plume, too. With a lidar ratio uncertainty of $25 \%$, particle density uncertainty of $15 \%$ and a conversion factor uncertainty of $20 \%$ we obtain mass concentration uncertainties of about $35 \%-40 \%$ in the lofted layer for the smoke particles.

Water-uptake effects and associated uncertainties in the retrieval of the mass concentrations of dry but hygroscopic smoke particles were estimated to be $<25 \%$. In most cases, SAMUM radiosonde launches at the lidar site indicated relative humidities clearly below $70 \%$. Saharan dust is almost hydrophobic so that water uptake does not play a role here.

The lidar-photometer consistency check revealed good agreement. As can be seen in Table 3, the total AOT was about 0.3 , with a dust fraction of 0.6 after eliminating a marine contribution of the order of 0.01 on that day (Groß et al., 2011a). AERONET photometer results for 22 January 2008 are only available as level 1.0 products. However, they are in good agreement with the quality-checked level 2.0 results for 23 January 2008 (early morning) and with observations of a second SAMUM photometer on 22 January 2008 (Toledano et al., 2011).

The dust AOT of 0.18 together with the column backscatter for the light-depolarizing particle fraction in Table 3 yield a dust column lidar ratio AOT/CB of $51.7 \mathrm{sr}$ which is again in the range of values typical for Saharan dust. Note the large lidar ratio for the fine mode which indicates strongly absorbing smoke particles (Tesche et al., 2011b). The Raman lidar ob- servations during that evening show smoke-related lidar ratios from $50-100 \mathrm{sr}$ at $532 \mathrm{~nm}$. The photometer-derived finemode AOT was 0.11 at about 18:30 UTC, while the Raman lidar observations after 20:00 UTC indicate a value of 0.080.09 so that the column lidar ratio fraction was obviously about $25 \%$ lower during the lidar measurement session than the value of $98 \mathrm{sr}$ in Table 3. Again, the good overall consistency of the entire observational data set corroborates the reliability of our mass retrieval approach.

\subsection{Eyjafjallajökull volcanic aerosol plume}

The evolution of the aerosol layering over Leipzig on 19 April 2010, 4-5 days after the strong eruptions of the Icelandic Eyjafjallajökull volcano is discussed by Ansmann et al. (2011b). A characteristic scene from the afternoon of that day is shown in Fig. 4. During this time period, a research aircraft (Falcon aircraft of German Aerospace Center) performed height-resolved in situ aerosol observations over Leipzig between 2-6 km height from 14:51-15:28 UTC (Schumann et al., 2011). The boundary layer reached maximum heights of about $1.4 \mathrm{~km}$ on 19 April 2010. However, the layer with strong backscattering reached to almost $3 \mathrm{~km}$ height (Fig. 4a). Above the boundary layer the atmosphere was dry with relative humidities of $50 \%-60 \%$ in the layer from $1.5-3 \mathrm{~km}$ height and below $25 \%$ higher up (Schumann et al., 2011). The depolarization ratio in Fig. $4 \mathrm{~b}$ indicates three layers, one with non-light-depolarizing particles (sulfate, urban haze) up to about $1.6 \mathrm{~km}$, and two layers with considerable depolarization from $1.8-2.8 \mathrm{~km}$ and from $3.8-5.5 \mathrm{~km}$ height caused by a mixture of fine- and coarse-mode particles. The backscatter and extinction profiles for fine and coarse mode show this more quantitatively (Fig. $4 \mathrm{c}$ and d). Volcanic dust mass concentrations of up to $250 \mu \mathrm{g} \mathrm{m}^{-3}\left(1.8-2.8 \mathrm{~km}\right.$ height) and $40 \mu \mathrm{g} \mathrm{m}^{-3}$ (3.8$5.5 \mathrm{~km}$ ) were derived (Fig. 4e). The aircraft observations revealed values of $50-250 \mu \mathrm{g} \mathrm{m}^{-3}$ and $15-40 \mu \mathrm{g} \mathrm{m}^{-3}$ in the respective layers. Relatively well-mixed conditions with mass concentrations of $50-80 \mu \mathrm{g} \mathrm{m}^{-3}$ were found from the lidar data for the fine-mode fraction in the lowermost $2 \mathrm{~km}$ of the atmosphere. Aged sulfate aerosol originating from the 


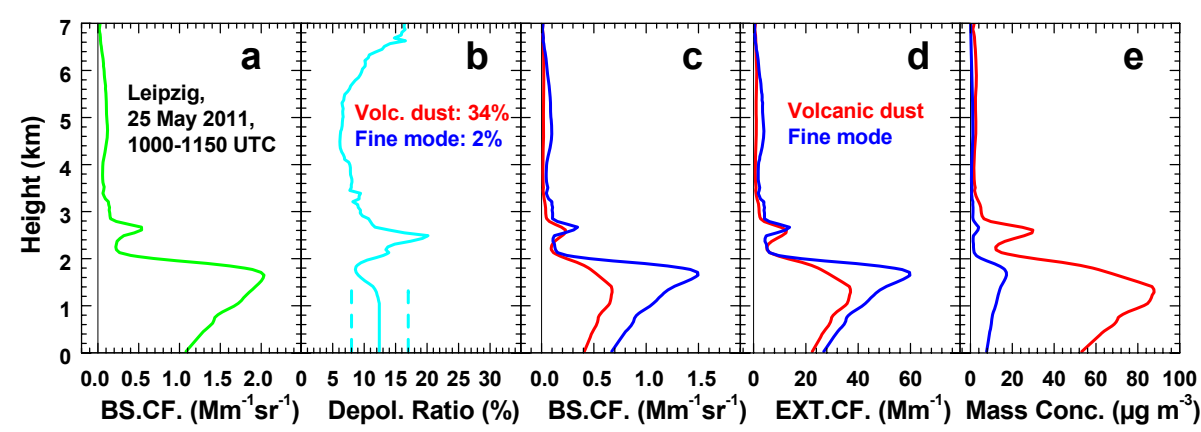

Fig. 5. Same as Fig. 2 except for Grimsvötn volcanic aerosol observed at Leipzig in May 2011. Dashed lines in (b) indicate the uncertainty range of derived values.

volcanic $\mathrm{SO}_{2}$ plumes considerably contributed to the finemode particle mass (about $50 \%$ ) on that day (Ansmann et al., 2011b).

The fine- and coarse-mode-related mass-specific extinction coefficients are $k_{\mathrm{ext}, \mathrm{c}}=0.64 \mathrm{~m}^{2} \mathrm{~g}^{-1}$ and $k_{\mathrm{ext}, \mathrm{f}}=$ $3.47 \mathrm{~m}^{2} \mathrm{~g}^{-1}$ in this case, with mean values of $v_{\mathrm{c}} / \tau_{\mathrm{c}}=0.60 \times$ $10^{-6} \mathrm{~m}$ and $v_{\mathrm{f}} / \tau_{\mathrm{f}}=0.18 \times 10^{-6} \mathrm{~m}$ according to Fig. 1 (case c). Lidar ratios of $55 \mathrm{sr}$ (volcanic dust) and $45 \mathrm{sr}$ (sulfate particles, found from the lidar-photometer consistency check) were used in the conversion of the backscatter into particle extinction coefficients shown in Fig. 4d.

The uncertainties in the coarse-mode backscatter coefficients in the two dust layers $(1.8-2.8 \mathrm{~km}$, above $3.8 \mathrm{~km}$ height) are $10 \%-15 \%$, again mainly caused by the assumption of the volcanic dust depolarization ratio of 0.34 with an uncertainty of 0.04 and of the fine-mode depolarization ratio of 0.02 with an uncertainty of 0.02 . Together with uncertainties in the measured volcanic dust lidar ratios of $10 \%$, of $15 \%$ in the estimated volcanic dust density, and of $20 \%$ in the $v_{\mathrm{c}} / \tau_{\mathrm{c}}$ values, we again obtain overall uncertainties in the mass concentrations of volcanic dust of about $30 \%$ in the two lofted volcanic dust layers. For the fine-mode, the backscatter coefficient uncertainty is about $10 \%$ up to $2 \mathrm{~km}$ height, and increases to $40 \%$ in $2.6 \mathrm{~km}$ height. Together with realistic uncertainties in the fine-mode lidar ratio of $25 \%$, of $15 \%$ in the particle density, and of $20 \%$ in the $v_{\mathrm{f}} / \tau_{\mathrm{f}}$ conversion factor we end up with an uncertainty of roughly $35 \%$ for heights $<2 \mathrm{~km}$, and up to $60 \%$ for heights up to $2.6 \mathrm{~km}$ height.

The total and fine-mode AOT were unusually high with values of 0.65 and 0.51 at $532 \mathrm{~nm}$, respectively (see Table 3). Together with basic lidar products (the CB values for nondepolarizing and light-depolarizing particles) we obtain column lidar ratios of about $45 \mathrm{sr}$ (fine mode) and almost $55 \mathrm{sr}$ for the volcanic dust. The derived fine-mode lidar ratio is typical for non-absorbing accumulation mode particles (Müller et al., 2007). The coarse-mode lidar ratio of $55 \mathrm{sr}$ is characteristic for volcanic dust (Ansmann et al., 2010; Groß et al., 2012). Again, the consistency check indicates a successful retrieval and trustworthy results.

\subsection{Grimsvötn volcanic aerosol}

According to reports of the Icelandic Meteorological Office (IMO) the eruptions of the ice-capped Eyjafjallajökull volcano in April 2010 were more explosive than the eruptions of the Grimsvötn volcano in May 2011 (http: //en.vedur.is/earthquakes-and-volcanism/articles/ne/2220

and http://en.vedur.is/earthquakes-and-volcanism/articles/ ne/2221). The latter also started as subglacial eruptions which, however, quickly broke the ice cover. Compared to the Eyjafjallajökull case, the Grimsvötn volcanic eruptions resulted in the release of coarser particulate matter according to the IMO report.

First volcanic plumes reached central Europe on 24 May 2011, about 2.5 days after the eruptions in the late afternoon of 21 May 2011. Tesche et al. (2012) provides information on the air mass transport towards central and northern Europe on 25 May 2011. A consistent air flow from the North Atlantic (Iceland area), across the UK towards Germany prevailed in the lowermost 3-4 km of the atmosphere on 25 and 26 May 2011 (until noon). Figure 5 presents lidar observations during the passage of the densest volcanic dust plumes. The volcanic particles crossed Leipzig at heights below $3.5 \mathrm{~km}$. In contrast to the Eyjafjallajökull volcanic dust plumes (mostly advected in the free troposphere), the Grimsvötn aerosol was mostly found in the boundary layer over Leipzig.

Above $4 \mathrm{~km}$ height further aerosol layers were detected on 25 May 2011. These layers were advected from southwesterly directions according to the transport simulations. They probably originated from North Africa and/or North America (mixture of desert dust and aged urban haze). Such lofted aerosols are a common feature over central Europe during the summer half year (Mattis et al., 2008). The AOT of the non-volcanic aerosols above $4 \mathrm{~km}$ height was estimated to be less than 0.008 and is thus ignored in the following discussion of lidar-photometer observations. The increasing particle depolarization ratio for heights above $6 \mathrm{~km}$ in Fig. $5 \mathrm{~b}$ is not be trustworthy. The uncertainty in the particle depolarization ratio steadily increases when the particle backscatter coefficient approaches zero. 
In agreement with the IMO report, the microphysical and optical properties of the Grimsvötn volcanic aerosol were found to be very different from the Eyjafjallajökull volcanic particle characteristics. Figure 1 indicates larger volcanic dust particles in May 2011. The mean value of $v_{\mathrm{c}} / \tau_{\mathrm{c}}$ of $0.90 \times 10^{-6} \mathrm{~m}$ for the Grimsvötn volcanic dust is $50 \%$ higher than the respective Eyjafjallajökull value of $0.60 \times 10^{-6} \mathrm{~m}$, which most probably reflects a significant shift of the size distribution towards larger particles (Gasteiger et al., 2011). The mass-specific extinction coefficient $k_{\text {ext, } \mathrm{c}}$ is $0.43 \mathrm{~m}^{2} \mathrm{~g}^{-1}$ for the Grimsvötn aerosol. The extinction coefficients in Fig. $5 \mathrm{~d}$ are computed with lidar ratios of $55 \mathrm{sr}$ for volcanic dust and $40 \mathrm{sr}$ for the fine-mode particles.

Because there was no layer which contained volcanic dust only, a specific Grimsvötn volcanic dust depolarization ratio could not be determined. Thus, we assume that the volcanic dust depolarization ratio for the Eyjafjallajökull event also holds for the Grimsvötn case in the separation of the backscatter coefficients for fine-mode and coarse-mode particles. Clearly, more depolarization observations of volcanic dust are needed to allow for a more general and accurate quantification of volcanic dust mass concentrations with polarization lidars.

The depolarization ratio values in Fig. 5b are shown with a large uncertainty range. The signal channel for crosspolarized light partly showed saturation effects at heights $<1.2 \mathrm{~km}$ during this event with unexpectedly strong depolarization return signals in the near range of the lidar. According to this large depolarization ratio uncertainty, the volcanic-dust-related backscatter coefficient is determined with an uncertainty of $40 \%$ for heights $<1.2 \mathrm{~km}$. The coarsemode backscatter coefficient is more accurately determined with $10 \%-15 \%$ relative error in the lofted layer centered at $2.5 \mathrm{~km}$ height. The overall uncertainty in the mass concentration retrieval for the volcanic dust particles is estimated to be $60 \%$ in the lowermost $1000 \mathrm{~m}$ of the atmosphere, and $30 \%$ in the lofted layer centered at $2.5 \mathrm{~km}$ height. For the fine-mode particles the overall uncertainty in the mass concentration retrieval is about $50 \%$ in the lowermost $1000 \mathrm{~m}$ of the atmosphere in this case.

On 25 May 2011, the volcanic dust was well-mixed throughout the boundary layer around local noon. Cumulus clouds developed from time to time during the measurement at the top of the boundary layer as detected with lidar. Therefore, we must assume high relative humidities of $>80$ to $90 \%$ in the upper boundary layer, even during cloud-free periods. At ground the relative humidity ranged from $35 \%-$ $45 \%$ according to the meteorological station of the institute. The high relative humidity in the upper boundary layer must be kept in consideration when discussing the mass concentrations.

The profiles in Fig. 5 are computed from cloud-screened signal profiles. The total backscatter coefficient in Fig. 5a indicates the increasing influence of water uptake by fine-mode as well as by the volcanic dust particles (Lathem et al., 2011).
The drop in the depolarization ratio in the upper part of the boundary layer $(1.4-2.0 \mathrm{~km})$ is consistent with a change in the shape properties of the volcanic dust particles. A part of the coarse particles became obviously spherical. Because of a potential water-uptake effect, the results in Fig. 5c, d, and e are not trustworthy for heights between 1.4 and $2.0 \mathrm{~km}$. Mass concentrations of volcanic dust are reliable only for heights $<1.4 \mathrm{~km}$ and from $2-3 \mathrm{~km}$ height. In the lower part of the boundary layer, the volcanic dust mass concentration ranged from 50-90 $\mathrm{g} \mathrm{m}^{-3}$. The very large fine-mode Ångström exponent of 2.7 in Table 3 indicates that a large number of freshly formed sulfate particles originating from the volcanic $\mathrm{SO}_{2}$ were present, too.

Tesche et al. (2012) analyzed in situ surface aerosol observations throughout Scandinavia on 24 and 25 May 2011 and included lidar observations at Stockholm, Sweden, in the study. The main volcanic aerosol plume crossed an area reaching from northern Germany to southern and middle Scandinavia. The time series of the surface observations showed a strong increase in coarse-particle mass concentrations when the first volcanic dust front crossed the observational site. The peak mass concentrations were close to $160 \mu \mathrm{g} \mathrm{m}^{-3}$ (Gothenburg, Sweden), $130 \mu \mathrm{g} \mathrm{m}^{-3}$ (Oslo, Norway, and Stockholm, Sweden) and $100 \mu \mathrm{g} \mathrm{m}^{-3}$ at Helsinki, Finland (Kerminen et al., 2011). By using the retrieval method presented here, volcanic dust mass concentrations were also estimated from the Stockholm lidar observations. The values range from $150-300 \mathrm{\mu g} \mathrm{m}^{-3}$ in the layer below $2 \mathrm{~km}$ height to $150-400 \mu \mathrm{g} \mathrm{m}^{-3}$ in a lofted layer from $2-4 \mathrm{~km}$ height detected over Stockholm in the early morning of 25 May 2011 (Tesche et al., 2012).

The water-uptake effect remains to be discussed in more detail. Lathem et al. (2011) show that volcanic dust particles are hygroscopic. The mean radius of volcanic dust particles was found to increase by $2 \%-10 \%$ when the relative humidity increases from $40 \%$ to $90 \%$. This means that the effective radius (area-weighted mean radius of the particle size distribution) increases by roughly $5 \%-20 \%$ which in turn leads to an increase in $v_{\mathrm{c}} / \tau_{\mathrm{c}}$ by $5 \%-20 \%$ (Gasteiger et al., 2011). On the other hand, water uptake leads to a decrease in particle density from 2.6 to $2.5 \mathrm{~g} \mathrm{~m}^{-3}$ ( $2 \%$ increase of radius) and from 2.6 to $2.1 \mathrm{~g} \mathrm{~m}^{-3}$ (10\% increase of radius). Most important however is that an increasing water content changes the shape characteristics of the originally non-spherical particles. A part of the volcanic dust particles became obviously spherical (about $10 \%$ according to the discussion below) and caused the strong decrease of the depolarization ratio in the upper part of the well-mixed boundary in Fig. 5.

The large spherical particles are then interpreted as finemode particles (according to our basic assumption that non-depolarizing particles are fine-mode particles). As a consequence, the column lidar ratio, i.e., the ratio of the finemode AOT (from the photometer observations) to the $\mathrm{CB}$ value caused by spherical particles (assumed to be the finemode CB) is rather low (below $25 \mathrm{sr}$ ) in Table 3 because of 
the strong contribution of backscattering of spherical coarsemode particles to the apparent fine-mode CB. Vice versa, the $\mathrm{CB}$ value for the coarse mode is too low and thus the column lidar ratio too high. As mentioned, a conversion of $10 \%$ of the originally non-spherical volcanic coarse-mode particles into spherical ones can explain the observed effect and the change of the column lidar ratios from typical values for fine particles of around $40 \mathrm{sr}$ to $22 \mathrm{sr}$ (fine mode) and from typical lidar ratios for volcanic dust of around $50 \mathrm{sr}$ to the observed one of close to $60 \mathrm{sr}$. The reason for this strong change in the optical effects by a likewise small change in the coarse-mode fraction of $10 \%$ is related to the fact that large spherical particles show a much higher reflectivity (i.e., a factor of 3 larger backscatter coefficients) than non-spherical particles of the same size.

\section{Conclusions}

We extended the range of applications of our polarization lidar photometer networking (POLIPHON) method, introduced after the volcanic eruptions in 2010, to Saharan dust events. We presented four very different situations of complex aerosol layering with fine and coarse particles. New volcanic dust observations performed after the Grimsvötn volcanic eruptions in May 2011 could be added to the discussion.

A key parameter in the retrieval of particle mass concentrations is the mass-specific extinction coefficient. Therefore, a review of the recent literature regarding specific extinction coefficients for desert dust and volcanic dust was performed.

Of fundamental importance for a successful application of the developed retrieval scheme is the assumption that the fraction of non-spherical light-depolarizing particles (as detected with lidar) represents well the coarse-mode particle fraction (particles with diameters $>1 \mu \mathrm{m}$ ) and, consequently, that the particle fraction which does not produce light depolarization, is almost identical with the fine-mode fraction.

We found that the retrieval scheme works well for continental aerosol mixtures consisting of dry volcanic or Saharan dust and biomass burning smoke, urban haze, and/or volcanic sulfate particles. In the case of volcanic aerosol layers, the method works well as long as the relative humidity is low enough so that significant water uptake by the volcanic dust particles does not play a role. Uncertainties can be large at relative humidities exceeding the $80 \%$ level because of wrong particle classification (fine versus coarse mode), and wrong assumptions in volcanic particle density, conversion factors and other input parameters.

The measurements (case studies) showed that Saharan dust loads can be very high over Europe during Saharan dust outbreaks. Mass concentrations of up to $400-500 \mu \mathrm{g} \mathrm{m}^{-3}$ occurred in the free troposphere (between 1-6 km height) over central Europe in May 2008. These values are similar to dust loads in the main outflow regime of Saharan dust over the western tropical Atlantic (Cape Verde). Extended, lofted aerosol layers consisting of mineral dust and biomassburning particles with smoke mass concentrations of the order of $10-35 \mu \mathrm{g} \mathrm{m}^{-3}$ were observed over Cape Verde during SAMUM-2 in the winter of 2008.

Volcanic aerosol plumes originating from the Eyjafjallajökull eruptions in April 2010 and the Grimsvötn eruptions observed over Leipzig in May 2011 were contrasted. A striking feature was that the volcanic dust was typically observed above the boundary layer at heights above $2 \mathrm{~km}$ in April 2010, while the Grimsvötn aerosol was mainly transported in the well-mixed, moist boundary layer at heights below $2 \mathrm{~km}$.

Based on the four case studies, the retrieval method was shown to be robust and applicable to very different scenarios. The method strongly relies on accurate lidar observations of the particle depolarization ratio. We definitely need more high-quality depolarization observations for volcanic aerosols such as they are available for Saharan dust, Asian dust, and the Eyjafjallajökull volcanic dust.

Acknowledgements. We would like to express our gratitude to the AERONET team for instrument calibration and data analysis. We are grateful to the IfT lidar team for establishing a rich data set of lidar observations.

Edited by: O. Dubovik

\section{References}

Ansmann, A., Wandinger, U., Riebesell, M., Weitkamp, C., and Michaelis, W.: Independent measurement of extinction and backscatter profiles in cirrus clouds by using a combined Raman elastic-backscatter lidar, Appl. Opt., 31, 7113-7131, 1992.

Ansmann, A., Althausen, D., Wandinger, U., Franke, K., Müller, D., Wagner, F., and Heintzenberg, J.: Vertical profiling of the Indian aerosol plume with six-wavelength lidar during INDOEX: A first case study, Geophys. Res. Lett., 27, p. 963, doi:10.1029/1999GL010902, 2000.

Ansmann, A., Bösenberg, J., Chaikovsky, A., Comerón, A., Eckhardt, S., Eixmann, R., Freudenthaler, V., Ginoux, P., Komguem, L., Linné, H., López Márquez, M. A., Matthias, V., Mattis, I., Mitev, V., Müller, D., Music, S., Nickovic, S., Pelon, J., Sauvage, L., Sobolewsky, P., Srivastava, M. K., Stohl, A., Torres, O., Vaughan, G., Wandinger, U., and Wiegner, M.: Long-range transport of Saharan dust to northern Europe: The 11-16 October 2001 outbreak observed with EARLINET, J. Geophys. Res., 108, 4783, doi:10.1029/2003JD003757, 2003.

Ansmann, A., and Müller, D., Lidar and atmospheric aerosol particles, in: LIDAR - Range-resolved optical remote sensing of the atmosphere, edited by: Weitkamp, C., Springer, New York, USA, 105-141, 2005.

Ansmann, A., Baars, H., Tesche, M., Müller, D., Althausen, D., Engelmann, R., Pauliquevis, T., and Artaxo, P.: Dust and smoke transport from Africa to South America: Lidar profiling over 
Cape Verde and the Amazon rainforest, Geophys. Res. Lett., 36, L11802, doi:10.1029/2009GL037923, 2009.

Ansmann, A., Tesche, M., Groß, S., Freudenthaler; V., Seifert, P., Hiebsch, A., Schmidt, J., Wandinger, U., Mattis, I., Müller, D., and Wiegner, M.: The 16 April 2010 major volcanic ash plume over central Europe: EARLINET lidar and AERONET photometer observations at Leipzig and Munich, Germany, Geophys. Res. Lett., 37, L13810, doi:10.1029/2010GL043809, 2010.

Ansmann, A., Petzold, A., Kandler, K., Tegen, I., Wendisch, M., Müller, D., Weinzierl, B., Müller, T., and Heintzenberg, J.: Saharan Mineral Dust Experiments SAMUM-1 and SAMUM-2: What have we learned?, Tellus B, 63, 403-429, doi:10.1111/j.1600-0889.2011.00555.x, 2011a.

Ansmann, A., Tesche, M., Seifert P, Groß, S., Freudenthaler, V., Apituley, A., Wilson, K. M., Serikov, I., Linné, H., Heinold, B., Hiebsch, A., Schnell, F., Schmidt, J., Mattis, I., Wandinger, U., and Wiegner, M.: Ash and fine-mode particle mass profiles from EARLINET-AERONET observations over central Europe after the eruptions of the Eyjafjallajökull volcano in 2010, J. Geophys. Res., 116, D00U02, doi:10.1029/2010JD015567, 2011 b.

Baars, H., Ansmann, A., Althausen, D., Engelmann, R., Artaxo, P., Pauliquevis, T., and Souza, R.: Further evidence for significant smoke transport from Africa to Amazonia, Geophys. Res. Lett., 38, L20802, doi:10.1029/2011GL049200, 2011.

Barnaba, F. and Gobbi, G. P.: Lidar estimation of tropospheric aerosol extinction, surface area and volume: Maritime and desert-dust cases, J. Geophys. Res., 106, 3005-3018, doi:10.1029/2000JD900492, 2001.

Barnaba, F. and Gobbi, G. P.: Correction to "Lidar estimation of tropospheric aerosol extinction, surface area and volume: Maritime and desert-dust cases" by F. Barnaba and G. P. Gobbi, J. Geophys. Res., 107, 4180, doi:10.1029/2002JD002340, 2002.

Barnaba, F. and Gobbi, G. P.: Aerosol seasonal variability over the Mediterranean region and relative impact of maritime, continental and Saharan dust particles over the basin from MODIS data in the year 2001, Atmos. Chem. Phys., 4, 2367-2391, doi:10.5194/acp-4-2367-2004, 2004.

Ben-Ami, Y., Koren, I., and Altaratz, O.: Patterns of North African dust transport over the Atlantic: winter vs. summer, based on CALIPSO first year data, Atmos. Chem. Phys., 9, 7867-7875, doi:10.5194/acp-9-7867-2009, 2009.

Ben-Ami, Y., Koren, I., Rudich, Y., Artaxo, P., Martin, S. T., and Andreae, M. O.: Transport of North African dust from the Bodélé depression to the Amazon Basin: A case study, Atmos. Chem. Phys., 10, 7533-7544, doi:10.5194/acp-10-7533-2010, 2010.

Bukowiecki, N., Zieger, P., Weingartner, E., Jurányi, Z., Gysel, M., Neininger, B., Schneider, B., Hueglin, C., Ulrich, A., Wichser, A., Henne, S., Brunner, D., Kaegi, R., Schwikowski, M., Tobler, L., Wienhold, F. G., Engel, I., Buchmann, B., Peter, T., and Baltensperger, U.: Ground-based and airborne in-situ measurements of the Eyjafjallajökull volcanic aerosol plume in Switzerland in spring 2010, Atmos. Chem. Phys., 11, 10011-10030, doi:10.5194/acp-11-10011-2011, 2011.

Chaikovsky, A., Dubovik, O., Goloub, P., Tanré, D., Pappalardo, G., Wandinger, U., Chaikovskaja, L., Denisov, S., Grudo, Y., Lopatsin, A., Karol, Y., Lapyonok, T., Korol, M., Osipenko, F., Savitsky, D., Slesar, A., Apituley, A., Alados-Arboledas, L., Binietoglou, I., Comerón, A., Granados-Muñoz, M. J., Papayanis, A., Perrone, M. R., Pietruczuk, A., De Tomasi, F., Wagner, J., and Wang, X.: Algorithm and software for the retrieval of vertical aerosol properties using combined lidar/radiometer data: dissemination in EARLINET network, Proceedings, 26th International Laser Radar Conference, Porto Heli, Greece, 2012.

Chazette, P., Bocquet, M., Royer, P., Winiarek, V., Raut, J.-C., Labazuy, P., Gouhier, M., Lardier, M., and Cariou, J.-P.: Eyjafjallajökull ash concentrations derived from both lidar and modeling, J. Geophys. Res., 117, D00U14, doi:10.1029/2011JD015755, 2012a.

Chazette, P., Dabas, A., Sanak, J., Lardier, M., and Royer, P.: French airborne lidar measurements for Eyjafjallajökull ash plume survey, Atmos. Chem. Phys., 12, 7059-7072, doi:10.5194/acp-127059-2012, 2012b.

Cozic, J., Verheggen, B., Weingartner, E., Crosier, J., Bower, K. N., Flynn, M., Coe, H., Henning, S., Steinbacher, M., Henne, S., Collaud Coen, M., Petzold, A., and Baltensperger, U.: Chemical composition of free tropospheric aerosol for $\mathrm{PM}_{1}$ and coarse mode at the high alpine site Jungfraujoch, Atmos. Chem. Phys., 8, 407-423, doi:10.5194/acp-8-407-2008, 2008.

Devenish, B.J., Thomson, D. J., Marenco, F., Leadbetter, S. J., Ricketts, H., and Dacre, H. F.: A study of the arrival over the United Kingdom in April 2010 of the Eyjafjallajökull ash cloud using ground-based lidar and numerical simulations, Atmos. Environ., 48, 152-164, 2012.

Dubovik, O., and King, M.: A flexible inversion algorithm for retrieval of aerosol optical properties from Sun and sky radiance measurements, J. Geophys. Res., 105, 20673-20696, 2000.

Dubovik, O., Sinyuk, A., Lapyonok, T., Holben, B., Mishchenko, M., Yang, P., Eck, T., Volten, H., Muñoz, O., Veihelmann, B., van der Zande, W. J., Leon, J. F., Sorokin, M., and Slutsker, I.: Application of spheroid models to account for aerosol particle non-sphericity in remote sensing of desert dust, J. Geophys. Res., 111, D11208, doi:10.1029/2005JD006619, 2006.

Engelmann, R., Ansmann, A., Fruntke, J., Seifert, P., Tesche, M., Althausen, D., Müller, D., Esselborn, M., Lieke, K., and Köhler, C.: Doppler lidar observations of heat-island effects on vertical mixing of dust and smoke over Cape Verde during SAMUM-2, Tellus B, 63, 448-458, doi:10.1111/j.1600-0889.2011.00552.x, 2011.

Franke, K., Ansmann, A., Müller, D., Althausen, D., Venkataraman, C., Reddy, M. S., Wagner, F., and Scheele, R.: Optical properties of the Indo-Asian haze layer over the tropical Indian Ocean, J. Geophys. Res., 108, 4059, doi:10.1029/2002JD002473, 2003.

Freudenthaler, V., Esselborn, M., Wiegner, M., Heese, B., Tesche, M., Ansmann, A., Müller, D., Althausen, D., Wirth, M., Fix, A., Ehret, G., Knippertz, P., Toledano, C., Gasteiger, J., Garhammer, M., and Seefeldner, M.: Depolarization ratio profiling at several wavelengths in pure Saharan dust during SAMUM 2006, Tellus B, 61, 165-179. doi:10.1111/j.1600-0889.2008.00396.x, 2009.

Gasteiger, J., Groß, S., Freudenthaler, V., and Wiegner, M.: Volcanic ash from Iceland over Munich: Mass concentration retrieved from ground-based remote sensing measurements, Atmos. Chem. Phys., 11, 2209-2223, doi:10.5194/acp-11-22092011, 2011.

Gobbi, G. P., Barnaba, F., Van Dingenen, R., Putaud, J. P., Mircea, M., and Facchini, M. C.: Lidar and in situ observations of continental and Saharan aerosol: closure analysis of particles optical and physical properties, Atmos. Chem. Phys., 3, 2161-2172, doi:10.5194/acp-3-2161-2003, 2003. 
Groß, S., Gasteiger, J., Freudenthaler, V., Wiegner, M., Geiß, A., Schladitz, A., Toledano, C., Kandler, K., Tesche, M., Ansmann, A., and Wiedensohler, A.: Characterization of the planetary boundary layer during SAMUM-2 by means of lidar measurements, Tellus B, 63, 695-705, doi:10.1111/j.16000889.2011.00557.x, 2011a.

Groß, S., Tesche, M., Freudenthaler, V., Toledano, C., Wiegner, M., Ansmann, A., Althausen, D., and Seefeldner, M.: Characterization of Saharan dust, marine aerosols and mixtures of biomassburning aerosols and dust by means of multi-wavelength depolarization and Raman lidar measurements during SAMUM 2, Tellus B, 63, 706-724, doi:10.1111/j.1600-0889.2011.00556.x, $2011 \mathrm{~b}$.

Groß, S., Freudenthaler, V., Wiegner, M., Gasteiger, J., Geiß, and Schnell F.: Dual-wavelength linear depolarization ratio of volcanic aerosols: Lidar measurements of the Eyjafjallajökull plume over Maisach, Germany, Atmos. Environ., 48, 85-96, 2012.

Hervo, M., Quennehen, B., Kristiansen, N. I., Boulon, J., Stohl, A., Fréville, P., Pichon, J.-M., Picard, D., Labazuy, P., Gouhier, M., Roger, J.-C., Colomb, A., Schwarzenboeck, A., and Sellegri, K.: Physical and optical properties of 2010 Eyjafjallajökull volcanic eruption aerosol: Ground-based, Lidar and airborne measurements in France, Atmos. Chem. Phys., 12, 1721-1736, doi:10.5194/acp-12-1721-2012, 2012.

Hess, M., Koepke, P., and Schult, I.: Optical properties of aerosols and clouds: The software package OPAC, B. Am. Meteorol. Soc., 79, 831-844, 1998.

Johnson, B. and Osborne, S. R.: Physical and optical properties of mineral dust aerosol measured by aircraft during the GERBILS campaign, Q. J. Roy. Meteor. Soc., 137, 1117-1130, 2011.

Johnson, B. T. T., Turnbull, K. F., Brown, P. R., Burgess, R., Dorsey, J. R., Baran, A. J., Webster, H. N., Haywood, J. M., Cotton, R., Ulanowski, J., Hesse, E., Woolley, A. M., and Rosenberg, P.: Insitu observations of volcanic ash clouds from the FAAM aircraft during the eruption of Eyjafjallajökull in 2010, J. Geophys. Res., 117, D00U24, doi:10.1029/2011JD016760, 2012.

Kandler, K., Schütz, L., Deutscher, C., Ebert, M., Hofmann, H., Jäckel, S., Jaenicke, R., Knippertz, P., Lieke, K., Massling, A., Petzold, A., Schladitz, A., Weinzierl, B., Wiedensohler, A., Zorn, S. and Weinbruch, S.: Size distribution, mass concentration, chemical and mineralogical composition and derived optical parameters of the boundary layer aerosol at Tinfou, Morocco, during SAMUM 2006. Tellus B, 61, 32-50, doi:10.1111/j.16000889.2008.00385.x, 2009.

Kandler, K., Schütz, L., Jäckel, S., Lieke, K., Emmel, C., MüllerEbert, D., Ebert, M., Scheuvens, D., Schladitz, A., Segvic, B., Wiedensohler, A. and Weinbruch, S.: Ground-based offline aerosol measurements at Praia, Cape Verde, during the Saharan Mineral Dust Experiment: microphysical properties and mineralogy, Tellus B, 63, 459-474, doi:10.1111/j.16000889.2011.00546.x, 2011.

Kerminen, V.-M., Niemi, J. V., Timonen, H., Aurela, M., Frey, A., Carbone, S., Saarikoski, S., Teinilä, K., Hakkarainen, J., Tamminen, J., Vira, J., Prank, M., Sofiev, M., and Hillamo, R.: Characterization of a volcanic ash episode in southern Finland caused by the Grimsvötn eruption in Iceland in May 2011, Atmos. Chem. Phys., 11, 12227-12239, doi:10.5194/acp-11-12227-2011, 2011.

Lathem, T. L., Kumar, P., Nenes, A., Dufek, J., Sokolik, I. N., Trail, M., and Russell, A.: Hygroscopic properties of volcanic ash, Geophys. Res. Lett., 38, L11802, doi:10.1029/2011GL047298,
2011.

Liu, D., Wang, Z., Liu, Z., Winker, D., and Trepte, C.: A height resolved global view of dust aerosols from the first year CALIPSO lidar measurements, J. Geophys. Res., 113, D16214, doi:10.1029/2007JD009776, 2008.

Marenco, F., Johnson, B., Turnbull, K., Newman, S., Haywood, J., Webster, H., and Ricketts, H.: Airborne lidar observations of the 2010 Eyjafjallajökull volcanic ash plume, J. Geophys. Res., 116, D00U05, doi:10.1029/2011JD016396, 2011.

Marenco, F. and Hogan, R., J.: Determining the contribution of volcanic ash and boundary layer aerosol in backscatter lidar returns: A three-component atmosphere approach, J. Geophys. Res., 116, D00U06, doi:10.1029/2010JD015415, 2011.

Mattis, I., Ansmann, A., Müller, D., Wandinger, U., and Althausen, D.: Dual-wavelength Raman lidar observations of the extinctionto-backscatter ratio of Saharan dust, Geophys. Res. Lett., 29, 1306, doi:10.1029/2002GL014721, 2002.

Mattis, I., Ansmann, A., Müller, D., Wandinger, U., and Althausen, D.: Multiyear aerosol observations with dual-wavelength Raman lidar in the framework of EARLINET, J. Geophys. Res., 109, D13203, doi:10.1029/2004JD004600, 2004.

Mattis, I., Müller, D., Ansmann, A., Wandinger, U., Preißler, J., Seifert, P., and Tesche, M.: Ten years of multiwavelength Raman lidar observations of free-tropopsheric aerosol layers over central Europe: Geometrical properties and annual cycle, J. Geophys. Res., 113, D20202, doi:10.1029/2007JD009636, 2008.

Mattis, I., Seifert, P., Müller, D., Tesche, M., Hiebsch, A., Kanitz, T., Schmidt, J., Finger, F., Wandinger, U., and Ansmann, A.: Volcanic aerosol layers observed with multiwavelength Raman lidar over central Europe in 2008-2009, J. Geophys. Res., 115, D00L04, doi:10.1029/2009JD013472, 2010.

Miffre, A., David, G., Thomas, B., and Rairoux, P.: Atmospheric non-spherical particles optical properties from UV-polarization lidar and scattering matrix, Geophys. Res. Lett., 38, L16804, doi:10.1029/2011GL048310, 2011.

Miffre, A., David, G., Thomas, B., Rairoux, P., Fjaeraa, A. M., Kristiansen, N. I., and Stohl, A.: Volcanic aerosol optical properties and phase partitioning behavior after long-range advection characterized by UV-Lidar measurements, Atmos. Environ., 48, 7684, 2012.

Mona, L., Amodeo, A., D’Amico, G., Giunta, A., Madonna, F., and Pappalardo, G.: Multi-wavelength Raman lidar observations of the Eyjafjallajökull volcanic cloud over Potenza, southern Italy, Atmos. Chem. Phys., 12, 2229-2244, doi:10.5194/acp-12-22292012, 2012.

Müller, D., Mattis, I., Wandinger, U., Ansmann, A., Althausen, D., Dubovik, O., Eckhardt, S., and Stohl, A.: Saharan dust over a central European EARLINET-AERONET site: Combined observations with Raman lidar and Sun photometer, J. Geophys. Res., 108, 4345, doi:10.1029/2002JD002918, 2003.

Müller, D., Ansmann, A., Mattis, I., Tesche, M., Wandinger, U., Althausen, D., and Pisani, G.: Aerosol-type-dependent lidar ratios observed with Raman lidar, J. Geophys. Res., 112, D16202, doi:10.1029/2006JD008292, 2007.

Müller, D., Veselovskii, I., Kolgotin, A., Tesche, M., Ansmann, A., and Dubovik, O.: Vertical profiles of pure dust (SAMUM-1) and mixed-smoke-dust plumes (SAMUM 2008) inferred from inversion of multiwavelength Raman/polarization lidar data and comparison to AERONET retrievals, Appl. Opt., submitted, 2012. 
Murayama, T., Okamoto, H., Kaneyasu, N., Kamataki, H., and Miura, K.: Application of lidar depolarization measurement in the atmospheric boundary layer: Effects of dust and sea-salt particles, J. Geophys. Res., 104, 31781-31792, doi:10.1029/1999JD900503, 1999.

Murayama, T., S. Masonis, J., Redemann, J., Anderson, T. L., Schmid, B., Livingston, J. M., Russel, P. B., Huebert, B., Howell, S. G., McNaughton, C. S., Clarke, A., Abo, M., Shimizu, A., Sugimoto, N., Yabuki, M., Kuze, H., Fukagawa, S., Maxwell-Meier, K., Weber, R. J., Orsini, D. A., Blomquist, B., Bandy, A., and Thornton, D.: An intercomparison of lidarderived aerosol optical properties with airborne measurements near Tokyo during ACE-Asia, J. Geophys. Res., 108, 8651, doi:10.1029/2002JD003259, 2003.

Nishizawa, T., Okamoto, H., Sugimoto, N., Matsui, I., Shimizu, A., and Aoki, K.: An algorithm that retrieves aerosol properties from dual-wavelength polarized lidar measurements, J. Geophys. Res., 112, D06212, doi:10.1029/2006JD007435, 2007.

O’Neill, N. T., Eck, T. F., Smirnov, A., Holben, B. N., and Thulasiraman, S.: Spectral discrimination of coarse and fine mode optical depth, J. Geophys. Res., 108, 4559, doi:10.1029/2002JD002975, 2003.

Osborne, S. R., Johnson, B. T., Haywood, J. M., Baran, A. J., Harrison, M. A. J., and McConnell, C. L.: Physical and optical properties of mineral dust aerosol during the Dust and Biomass-burning Experiment, J. Geophys. Res., 113, D00C03, doi:10.1029/2007JD009551, 2008.

Papayannis, A., Amiridis, V., Mona, L., Tsaknakis, G., Balis, D., Bösenberg, J., Chaikovski, A., De Tomasi, F., Grigorov, I., Mattis, I., Mitev, V., Müller, D., Nickovic, S., Pérez, C., Pietruczuk, A., Pisani, G., Ravetta, F., Rizi, V., Sicard, M., Trickl, T., Wiegner, M., Gerding, M., Mamouri, R. E., D’Amico, G., and Pappalardo, G.: Systematic lidar observations of Saharan dust over Europe in the frame of EARLINET (2000-2002), J. Geophys. Res., 113, D10204, doi:10.1029/2007JD009028, 2008.

Papayannis, A., Mamouri, R. E., Amiridis, V., Giannakaki, E., Veselovskii, I., Kokkalis, P., Tsaknakis, G., Balis, D., Kristiansen, N. I., Stohl, A., Korenskiy, M., Allakhverdiev, K., Huseyinoglu, M. F., and Baykara, T.: Optical properties and vertical extension of aged ash layers over the Eastern Mediterranean as observed by Raman lidars during the Eyjafjallajökull eruption in May 2010, Atmos. Environ., 48, 56-65, 2012.

Pappalardo, G., Amodeo, A., Mona, L., Pandolfi, M., Pergola, N., and Cuomo, V.: Raman lidar observations of aerosol emitted during the 2002 Etna eruption, Geophys. Res. Lett., 31, L05120, doi:10.1029/2003GL019073, 2004.

Pornsawad, P., D’Amico, G., Böckmann, C., Amodeo, A., and Pappalardo, G.: Retrieval of aerosol extinction coefficient profiles from Raman lidar data by inversion method, Appl. Opt., 51, 2035-2044, 2012.

Reid, J. S., Koppmann, R., Eck, T. F., and Eleuterio, D. P.: A review of biomass burning emissions part II: intensive physical properties of biomass burning particles, Atmos. Chem. Phys., 5, 799825, doi:10.5194/acp-5-799-2005, 2005.

Sakai, T., Nagai, T., Nakazato, M., Mano, Y., and Matsumura, T.: Ice clouds and Asian dust studied with lidar measurements of particle extinction-to-backscatter ratio, particle depolarization, and water vapour mixing ratio over Tsukuba, Appl. Opt., 42, 7103-7116, 2003a.
Sakai, T., Shibata, T., Hara, K., Kido, M., Osada, K., Hayashi, M., Matsunaga, K., and Iwasaka, Y.: Raman lidar and aircraft measurements of tropospheric aerosol particles during the Asian dust event over central Japan: Case study on 23 April 1996, J. Geophys. Res., 108, 4349, doi:10.1029/2002JD003150, 2003b.

Sakai, T., Nagai, T., Zaizen, Y, and Mano, Y.: Backscattering linear depolarization ratio measurements of mineral, sea-salt, and ammonium sulfate particles simulated in a laboratory chamber, Appl. Opt., 49, 4441-4449, 2010.

Samoilova, S. V., and Balin, Y. S.: Reconstruction of the aerosol optical parameters from the data of sensing with a multifrequency Raman lidar, Appl. Opt., 47, 6816-6831, 2008.

Sassen, K.: Polarization in lidar, in: LIDAR - Range-resolved optical remote sensing of the atmosphere, edited by: Weitkamp, C., Springer, New York, USA, 19-42, 2005.

Sassen, K., Zhu, J., Webley, P., Dean, K., and Cobb, P.: Volcanic ash plume identification using polarization lidar: Augustine eruption, Alaska, Geophys. Res. Lett., 34, L08803, doi:10.1029/2006GL027237, 2007.

Schumann, U., Weinzierl, B., Reitebuch, O., Schlager, H., Minikin, A., Forster, C., Baumann, R., Sailer, T., Graf, K., Mannstein, H., Voigt, C., Rahm, S., Simmet, R., Scheibe, M., Lichtenstern, M., Stock, P., Rüba, H., Schäuble, D., Tafferner, A., Rautenhaus, M., Gerz, T., Ziereis, H., Krautstrunk, M., Mallaun, C., Gayet, J.F., Lieke, K., Kandler, K., Ebert, M., Weinbruch, S., Stohl, A., Gasteiger, J., Groß, S., Freudenthaler, V., Wiegner, M., Ansmann, A., Tesche, M., Olafsson, H., and Sturm, K.: Airborne observations of the Eyjafjalla volcano ash cloud over Europe during air space closure in April and May 2010, Atmos. Chem. Phys., 11, 2245-2279, doi:10.5194/acp-11-2245-2011, 2011.

Shcherbakov, V.: Regularization algorithm for Raman lidar data processing, Appl. Opt., 46, 4879-4889, 2007.

Shimizu, A., Sugimoto, N., Matsui, I., Arao, K., Uno, I., Murayama, T., Kagawa, N., Aoki, K., Uchiyama, A., and Yamazaki, A.: Continuous observations of Asian dust and other aerosols by polarization lidars in China and Japan during ACE-Asia, J. Geophys. Res., 109, D19S17, doi:10.1029/2002JD003253, 2004.

Sicard, M., Guerrero-Rascado, J. L., Navas-Guzmán, F., Preißler, J., Molero, F., Tomás, S., Bravo-Aranda, J. A., Comerón, A., Rocadenbosch, F., Wagner, F., Pujadas, M., and Alados-Arboledas, L.: Monitoring of the Eyjafjallajökull volcanic aerosol plume over the Iberian Peninsula by means of four EARLINET lidar stations, Atmos. Chem. Phys., 12, 3115-3130, doi:10.5194/acp-12-31152012, 2012.

Sugimoto, N. and Lee, C. H.: Characteristics of dust aerosols inferred from lidar depolarization measurements at two wavelength, Appl. Opt., 45, 7468-7474, 2006.

Sugimoto, N., Uno, I., Nishikawa, M., Shimizu, A., Matsui, I., Dong, X., Chen, Y., and Quan, H.: Record heavy Asian dust in Beijing in 2002: Observations and model analysis of recent events. Geophys. Res. Lett., 30, 1640, doi:10.1029/2002GL016349, 2003.

Tang, I., and Munkelwitz, H.: Water activities, densities, and refractive indices of aqueous sulfates and sodium nitrate droplets of atmospheric importance, J. Geophys. Res., 99, 18801-18808, doi:10.1029/94JD01345, 1994.

Tesche, M., Ansmann, A., Müller, D., Althausen, D., Mattis, I., Heese, B., Freudenthaler, V., Wiegner, M., Esselborn, M., Pisani, G., and Knippertz, P.: Vertical profiling of Saharan dust 
with Raman lidars and airborne HSRL in southern Morocco during SAMUM, Tellus B, 61, 144-164, doi:10.1111/j.16000889.2008.00390.x, 2009a.

Tesche, M., Ansmann, A., Müller, D., Althausen, D., Engelmann, R., Freudenthaler, V., and Groß, S.: Vertically resolved separation of dust and smoke over Cape Verde using multiwavelength Raman and polarization lidars during Saharan Mineral Dust Experiment 2008, J. Geophys. Res., 114, D13202, doi:10.1029/2009JD011862, 2009b.

Tesche, M., Groß, S., Ansmann, A., Müller, D., Althausen, D., Freudenthaler, V., and Esselborn, M.: Profiling of Saharan dust and biomass-burning smoke with multiwavelength polarization Raman lidar at Cape Verde, Tellus B, 63, 649-676, doi:10.1111/j.1600-0889.2011.00548.x, 2011a.

Tesche, M., Müller, D., Groß, S., Ansmann, A., Althausen, D., Freudenthaler, V., Weinzierl, B., Veira, A., and Petzold, A.: Optical and microphysical properties of smoke over Cape Verde inferred from multiwavelength lidar measurements. Tellus B, 63, 677-694. doi:10.1111/j.1600-0889.2011.00549.x, 2011b.

Tesche M.: Vertical profiling of aerosol optical properties with multiwavelength aerosol lidar during the Saharan Mineral Dust Experiments, PhD thesis, University of Leipzig, 163 pp., Leibniz Institute for Tropospheric Research, Leipzig, Germany, 2011c.

Tesche, M., Glantz, P., Johansson, C., Norman, M., Hiebsch, A., Ansmann, A., Althausen, D., Engelmann, R., and Seifert, P.: Volcanic ash over Scandinavia originating from the Grimsvötn eruptions in May 2011, J. Geophys. Res., 117, D09201, doi:10.1029/2011JD017090, 2012.

Toledano, C., Wiegner, M., Groß, S., Freudenthaler, V., Gasteiger, J., Müller, D., Müller, T., Schladitz, A., Weinzierl, B., Torres, B., and O'Neill, N. T.: Optical properties of aerosol mixtures derived from sun-sky radiometry during SAMUM-2, Tellus B, 63, 635648, doi:10.1111/j.1600-0889.2011.00573.x, 2011.

Toledano, C., Bennouna, Y., Cachorro, V., Ortiz de Galisteo, J. P., Stohl, A., Stebel, K., Kristiansen, N. I., Olmo, F. J., Lyamani, H., Obregón, M. A., Estellés, V., Wagner, F., Baldasano, J. M., González-Castanedo, Y., Clarisse, L., and de Frutos, A. M.: Aerosol properties of the Eyjafjallajökull ash derived from sun photometer and satellite observations over the Iberian Peninsula, Atmos. Environ., 48, 22-32, 2012.
Turnbull, K. F., Johnson, B. T., Marenco, F., Haywood, J., Minikin, A., Weinzierl, B., Schlager, H., Schumann, U., Leadbetter, S. J., and Woolley, A. M.: A case study of observations of volcanic ash from the Eyjafjallajökull eruption, part 1: In situ airborne observations, J. Geophys. Res., 117, D00U12, doi:10.1029/2011JD016688, 2012.

Veselovskii I., Dubovik, O., Kolgotin, A., Korenskiy, M., Whiteman, D. N., Allakhverdiev, K., and Huseyinoglu, F.: Linear estimation of particle bulk parameters from multi-wavelength lidar measurements, Atmos. Meas. Tech., 5, 1135-1145, doi:10.5194/amt-5-1135-2012, 2012.

Wagner, J., Wandinger, U., Ansmann, A., Seifert, P., and Chaikovsky, A.: Evaluation of a combined lidar and sunphotometer retrieval algorithm to determine aerosol microphysical properties, Proceedings, 26th International Laser Radar Conference, Porto Heli, Greece, 2012.

Wang, X., Boselli, A., D’Avinoa, L., Pisani, G., Spinelli, N., Amodeo, A., Chaikovsky, A., Wiegner, M., Nickovic, S., Papayannis, A., Perrone, M. R., Rizzi, V., Sauvage, J., and Stohl, A.: Volcanic dust characterization by EARLINET during Etna's eruptions in 2001-2002, Atmos. Environ., 42, 893-905, 2008.

Weinzierl, B., Petzold, A., Esselborn, M., Wirth, M., Rasp, K., Kandler, K., Schütz, L., Koepke, P., and Fiebig, M.: Airborne measurements of dust layer properties, particle size distribution and mixing state of Saharan dust during SAMUM 2006, Tellus B, 61, 96-117, doi:10.1111/j.1600-0889.2008.00392.x, 2009.

Wiegner, M., Groß, S., Freudenthaler, V., Schnell, F., and Gasteiger, J.: The May/June 2008 Saharan dust event over Munich: Intensive aerosol parameters from lidar measurements, J. Geophys. Res., 116, D23213, doi:10.1029/2011JD016619, 2011.

Wiegner, M., Gasteiger, J., Groß, S., Schnell, F., Freudenthaler, V., and Forkel, R.: Characterization of the Eyjafjallajökull ashplume: Potential of lidar remote sensing, J. Phys. Chem. Earth, 45-46, 79-86, doi:10.1016/j.pce.2011.01.006, 2012.

Winker, D. M., Liu, Z., Omar, A., Tackett, J., and Fairlie, D.: CALIOP observations of the transport of ash from the Eyjafjallajökull volcano in April 2010, J. Geophys. Res., 117, D00U15, doi:10.1029/2011JD016499, 2012. 